\title{
Bitlis’teki Tüketicilerin Gıda Güvenliği ve Gıda Hijyeni Konusundaki Bilgi ve Tutumları
}

\author{
Seda OĞUR* \\ Bitlis Eren Üniversitesi, Mühendislik-Mimarlık Fakültesi, Gıda Mühendisliği Bölümü \\ (ORCID: 0000-0002-2041-0790)
}

\begin{abstract}
$\ddot{O ̈ z}$
$\mathrm{Bu}$ araştırmada, Bitlis il merkezinde ikamet eden tüketicilerin gıda güvenliği ve gıda hijyeni konusundaki bilgi ve tutumlarının belirlenmesi amaçlanmıştır. 2015 yılının Şubat ayında yürütülen araştırmada, gelişigüzel örnekleme yöntemiyle seçilen 405 katılımcının yaş, cinsiyet, eğitim düzeyi ve meslek bilgileri ile gıda güvenliği ve gıda hijyeni ile ilgili ürünü satın almadan tüketinceye kadar dikkate almaları gereken 40 ifadeden oluşan bir anket formu uygulanmıştır. Elde edilen veriler IBM SPSS $20{ }^{\circledR}$ programında sıklık, bağımsız T-testi ve Pearson Ki-kare $\left(\chi^{2}\right)$ testleriyle değerlendirilmiştir. Ankete katılan tüketicilerin yaş ortalamalarının 30.62 $9.45, \% 53.6$ 'sının kadın, \%46.4'ünün erkek, \%67.4'ünün üniversite mezunu, \%20.7'sinin lise mezunu, \%9.9'unun ilköğretim mezunu, $\% 32.3$ 'ünün büro memuru ve \%16.3'ünün ev hanımı olduğu belirlenmiştir. Tüketicilerin \%84.0'ü gıda ürünlerini satın alırken son kullanma tarihlerine dikkat ettiğini, \%87.2'si ambalajsız gıda ürünü alırken tazeliğine, temizliğine dikkat ettiğini, \%90.1'i sebze ve meyveleri temiz ve bol su ile yıkadığını, \%49.9'u markalı ürünlerin her zaman kaliteli ve güvenilir olduğuna kısmen katıldığını, \%69.6'sı yemekleri pişirirken ya da tekrar isıtırken uygun sıcaklıkta olduğunu anlamak için termometre kullanmadığını, \%45.7'si reklamların ürün hakkında gerekli bilgileri verdiğine katılmadığını ifade etmiştir. Tüketicilerin cinsiyetleri ile gıdayı hijyenik şartlarda hazırlama ve saklama konusundaki tutumlarını belirleyen ifadelere (14.-26. ifadeler) verdikleri yanıtlar arasındaki farkın ve eğitim düzeyleri ve meslekleri ile "Satın aldığım gıda ürünlerinin etiket bilgilerini okurum." ve "Yiyeceklerin protein ve vitamin içeriklerini bilirim, bilmediklerimi öğrenmeye gayret ederim." ifadelerine verdikleri yanıtlar arasındaki farkın anlamlı $(\mathrm{P}<0.05)$ olduğu bulunmuștur. Gıda güvenliği ve gıda hijyeni ile ilgili olarak en önemli olduğunu düşündüğümüz bilgiler ve uygulamalar konusunda; katılımcıların doğru bilgi veya doğru alışkanlık sahibi olmaları ile eğitim seviyesi arasındaki ilişkinin beklenildiği şekilde anlamlı olmadığı gözlemlenmiştir.
\end{abstract}

Anahtar kelimeler: Gıda güvenliği, gıda hijyeni, tüketici, bilgi, tutum.

\section{Knowledge and Attitudes of Consumers in Bitlis about Food Safety and Food Hygiene}

\begin{abstract}
This study aimed to determine the level of knowledge and attitudes of consumers residing in the province of Bitlis center about food safety and food hygiene. The study was conducted in February 2015, a questionnaire consisting of informations related to gender, age, education level, profession and 40 questions related to food safety and food hygiene (during from buying until consumption) was applied to 405 individuals, selected by randomly sampling method. Data obtained were analyzed by the IBM SPSS $20 ®$ program with frequency, independent T-test and Pearson chi-square $\left(\chi^{2}\right)$ tests. It was determined that age average of consumers participating in the survey was $30.62 \pm 9: 45,53.6 \%$ of them were female, $46.4 \%$ of them were male, $67.4 \%$ of them were university graduate, $20.7 \%$ of them were high school graduate, $9.9 \%$ of them were elementary school graduate, $27.9 \%$ of them were government official and $16.3 \%$ of them were housewife. $84.0 \%$ of consumers stated that they pay attention to expiration dates when purchasing food products; $87.2 \%$ of them stated that they consider the freshness and cleanliness when purchasing food products; $90.1 \%$ of them stated that they wash fruits and vegetables with clean and abundant water; $49.9 \%$ of them stated that they agree partially with branded products are always quality and reliable; $69.6 \%$ of them stated that they do not use thermometer to understand whether the meal in appropriate temperature when cooking or reheat; $45.7 \%$ of them stated that they do not agree with ads give the necessary
\end{abstract}

*Sorumlu yazar: ogursd@gmail.com

Geliş Tarihi: 26.06.2019, Kabul Tarihi: 18.10.2019 
information about product. A significant difference $(\mathrm{P}<0.05)$ was found between gender and read the label information of the food I buy" and of "I know protein and vitamin contents of foods and try to learn what I don't know". In terms of information and practices that we think are most important related with food safety and food hygiene, it was observed that the relationship between the participants' having the right information or having the right habits and the education level was not significant as expected. Responses given to expressions (14.-26. expressions) that determine their attitudes about preparing and storing the foods under hygienic conditions, and between education level, profession and responses given to expressions of "I read the label information of the food I buy" and of "I know protein and vitamin contents of foods and try to learn what I don't know". In terms of information and practices that we think are most important related with food safety and food hygiene, it was observed that the relationship between the participants' having the correct information or having the right habits and the education level was not significant as expected.

Keywords: Food safety, food hygiene, consumer, knowledge, attitude.

\section{Giriş}

Gıda güvenliği; amaçlandığı biçimde hazırlandığında, fiziksel, kimyasal ve biyolojik özellikleri itibarı ile tüketime uygun ve besin değerini kaybetmemiş gıda maddesi üretmek olarak tanımlanmaktadır [1]. Gıda hijyeni ise; insan tüketimine uygun gıda üretebilmek için, gıdanın kullanım amacı dikkate alınarak; tehlikelerin kontrol altına alınması ve üretim aşamalarında gerekli kurallara uyulması ve önlemlerin alınmasidır [2].

Gıda güvenliğinin yoksunluğu ülkesel ve küresel sorunlara neden olmaktadır [3]. Gıda kaynaklı enfeksiyonlar hem gelişmiş hem de gelişmekte olan ülkelerin en önemli halk sağlığı sorunları arasında yer almaktadır. FAO ve WHO Gıda Güvenliği Uzman Komitesi, kontamine gıda tüketiminden doğan gıda kaynaklı hastalıkların dünyadaki en sık görülen sağlık sorunu olduğunu işaret etmektedir [4].

Her türlü bozulma ve bulaşmaya yol açan etkenden arındırılarak tüketime uygun hale getirilmiş gıda, güvenli gıda olarak nitelendirilmektedir. Gıdanın güvenli olması için üretiminden tüketilinceye kadar her aşamada hijyen kurallarına uyulması tüketicilerin sağlığının korunması için kaçınılmaz bir unsurdur. Bu hususta en büyük sorumluluk devletten ve üreticilerden çok tüketicilere düşmektedir. Çünkü bilinçli bir tüketicinin ürünü satın alması ile başlayan, ürünü pişirinceye ya da hazırlayıncaya kadar muhafaza etmesi, ürünü hazırladıktan ya da pişirdikten sonra tüketinceye kadar saklaması ve tüketmesi ile devam eden süreçte uyması ya da dikkat etmesi gereken gıda güvenliği ve gıda hijyeni ile ilgili kurallara riayet etmemesi durumunda sağlığı olumsuz etkilenebilmektedir [5-7]. Çeşitli araştırmalarda [8-11] tüketicilerin ve gıda sektörü çalışanlarının yiyecek hazırlama güvenliği açısından bilgi eksikliği ve ihmalleri ortaya çıkarılmıştır.

Tüketicilerin gıda kaynaklı tehlikelere karşı kendilerini koruyabilmeleri için karşılaşabilecekleri risklerle ilgili yeterli bilgiye sahip olmaları gerekmektedir. Bilinçli tüketici; satın aldığı hizmet ve maldan bir yarar sağlamayı amaç edinmiş, güvenli, sağlılı, kaliteli, çevreye zararı olmayan ürün seçiminde bulunan kişiye denmektedir. Teknolojinin gelişmesi, internet, televizyon, radyo vb. iletişim araçları sayesinde tüketicilerin güvenli gıda ürünü hakkında bilinç düzeyleri de gelişmiştir. Tüketiciler bu konuda bilinçli hale geldikçe tüketicinin satın alma davranışında değişimler meydana gelmiş ve sonuçta ürün tercihlerinde farklılıklar ortaya çıkmıştır. Toplumdaki bilinçli tüketici sayısının artmasıyla beraber tüketici davranışları kavramının önemi ve bu konuda yapılan araştırmalar oldukça arttırmıştır [12].

Günümüz koşullarında, büyük şehirlerdeki yoğun ve hızlı yaşam akışı içinde, sağlıklı bir hayat sürdürebilmek için tüketicilerin bu konularda doğru bilgi edinmeleri ve bunları her zaman doğru şekilde uygulamaya özen göstermeleri büyük öneme sahiptir. Çocukluk çağından itibaren bu konulardaki bilgi, kural ve uygulamalara eğitim sistemi içinde bilgilendirici seminerler veya fen, sağlık veya biyoloji ders müfredatı içinde yer verilmeli, her alanda olduğu gibi bu konularda da eğitimin önemi unutulmamalıdır $[6,13]$.

Gıda güvenliği ve gıda hijyeni ile ilgili olan, gerekli bilgi ve uygulamaların doğrusu öğrenilmeli ve öğrenilen bilgi ve uygulamalar alışkanlık haline getirilerek sürdürülebilirliği sağlanmalıdır.

Yürütülen çalışmada Bitlis il merkezinde ikamet eden tüketicilerin gıda ürününü satın almadan, evlerinde hazırlayıp tüketmelerine kadar geçen sürede uymaları veya dikkat etmeleri gereken, gıda güvenliği ve gıda hijyeni ile ilgili bazı önemli faktörler hakkındaki bilgi düzeyleri ve bu konulardaki 
asıl tutum ve davranışlarının cinsiyet, eğitim düzeyi ve meslek değişkenlerine göre belirlenmesi amaçlanmıştır.

\section{Materyal ve Metot}

Araştırmaya başlanmadan önce Bitlis Eren Üniversitesi Etik Kurul Başkanlığından Etik Kurul İzni (Tarih: 12.02.2015, Sayı: 2094) alınmıștır. Kesitsel araştırma olarak planlanan, 2015 yılının Şubat ayında yürütülen çalışmanın evrenini Bitlis il merkezinde ikamet eden, 18 yaş üzeri bireyler oluşturmuştur. Gelişigüzel örnekleme yöntemiyle seçilen, 405 gönüllü katılımcıya çalışmanın amacı ve kapsamı anlatılarak; kendileri bilgilendirildikten sonra onayları alınmış ve yaş, cinsiyet, eğitim düzeyi ve meslek bilgileri ile gıda güvenliği ve gıda hijyeni ile ilgili ürünü satın almadan tüketinceye kadar uymaları veya dikkat etmeleri gereken 40 ifadeden oluşan bir anket formu yüz yüze görüşülerek uygulanmıştır. Anketler Bitlis Eren Üniversitesi çevresindeki okullar, valilik, belediye, emniyet müdürlügü, hastane, sağlık ocağı gibi resmi kurumlarda çalışan ve yakın mahallelerdeki evlerde ikamet eden kişilerle gerçekleştirilmiştir.

Ankette yer alan 40 ifadede gıda güvenliği ve gıda hijyeni ile ilgili 4 faktör ele alınmıştır. $\mathrm{Bu}$ faktörler şunlardır: 1. Tüketicilerin gıda ürünü satın almadaki bilinç düzeyleri (1.-10. ifadeler), 2. Tüketicilerin gıda ürünü satın almada etkilendikleri unsurlar (11.-13. ifadeler), 3. Tüketicilerin gıdayı hijyenik şartlarda hazırlama ve saklama konusundaki tutumları (14.-26. ifadeler), 4. Tüketicilerin gıda güvenliği ile ilgili konulardaki bilgi düzeyleri ve davranışları (27.-40. ifadeler). Ankette 3 dereceli likert bir ölçek (kesinlikle katılıyorum, kısmen katılıyorum, kesinlikle katılmıyorum) kullanılmıştır.

Anketlerin uygulanmasından sonra elde edilen veriler IBM SPSS $23 \AA$ programında sıklık, bağımsız T-testi ve Pearson ki-kare $\left(\chi^{2}\right)$ testleriyle değerlendirilmiş, $\mathrm{P}<0.05$ düzeyi istatistiki açıdan anlamlı kabul edilmiştir. Tüketicilerin gida güvenliği ve gida hijyeni ile ilgili bilgi ve tutumlarının cinsiyet, eğitim düzeyi ve meslek değişkenine göre farklılık gösterip göstermediği belirlenmeye çalışılmıştır.

\section{Bulgular ve Tartışma}

Tüketicilerin yaş ortalamalarının $30.62 \pm 9.45$ olduğu tespit edilmiş ve bazı sosyodemografik özellikleri Tablo 1'de verilmiştir.

Tablo 1. Tüketicilerin bazı sosyodemografik özellikleri

\begin{tabular}{|c|c|c|}
\hline Cinsiyet & $\mathbf{s}$ & $\%$ \\
\hline Bayan & 217 & 53.6 \\
\hline Erkek & 188 & 46.4 \\
\hline \multicolumn{3}{|l|}{ Eğitim Düzeyi } \\
\hline Ĕ̆itimi yok & 8 & 2.0 \\
\hline Ilköğretim mezunu & 40 & 9.9 \\
\hline Lise mezunu & 84 & 20.7 \\
\hline Üniversite mezunu & 273 & 67.4 \\
\hline \multicolumn{3}{|l|}{ Meslek } \\
\hline Büro memuru & 131 & 32.3 \\
\hline Ev hanımı & 66 & 16.3 \\
\hline Öğrenci & 43 & 10.6 \\
\hline Hemşire & 32 & 7.9 \\
\hline Tekniker & 15 & 3.7 \\
\hline Özel güvenlik & 14 & 3.5 \\
\hline Öğretim üyesi & 13 & 3.2 \\
\hline Öğretmen & 12 & 3.0 \\
\hline Mühendis & 12 & 3.0 \\
\hline İsçi & 11 & 2.7 \\
\hline Serbest meslek & 11 & 2.7 \\
\hline Diğerleri* & 45 & 11.1 \\
\hline
\end{tabular}


Tüketicilerin \%53.6'sının bayan, \%46.4'ünün erkek, \%67.4'ünün üniversite mezunu, \%32.3'ünün büro memuru ve \%16.3'ünün ev hanımı olduğu belirlenmiştir (Tablo 1). Anketler daha çok Bitlis Eren Üniversitesi çevresindeki okullar, valilik, belediye, emniyet müdürlüğü, hastane, sağlık ocağ gibi resmi kurumlarda gerçekleştirildiği için katılımcı büro memurlarının oranı yüksek olmuştur.

Tüketicilerin gıda güvenliği ve gıda hijyeni ile ilgili ifadelere verdikleri yanıtların dağılımı Tablo 2'de verilmiştir. Tüketicilerin gıda ürünü satın almadaki bilinç düzeyleri ile ilgili ifadelere verdikleri yanıtlara bakıldığında; "Gıda ürünlerini satın alırken son kullanma tarihlerine kesinlikle dikkat ederim." ifadesine; tüketicilerin \%84.0'ü kesinlikle katıldığını, \%14.8'i kısmen katıldığını, \%1.2'si kesinlikle katılmadığını belirtmiştir (Tablo 2). Topuzoğlu ve ark. [14]'nın çalışmasında aynı ifadeye katılan tüketicilerin oranı \%39.6 olarak bulunmuştur. Tüketicilerin \%45.2'si "Açıkta satılan yiyecekleri kesinlikle satın almam." ifadesine; "kesinlikle katılıyorum", \%45.4'ü "kismen kat1lyorum", \%9.4'ü "kesinlikle katılmıyorum" yanıtını vermiştir (Tablo 2).

İşlenmemiş gıda ürünlerini taze halde, işlenmiş gıda ürünlerini ise proses sonrası özelliklerini koruyup istenildiği kalitede tüketiciye ulaştırmayı sağlayan çeşitli ambalaj malzemelerinden faydalanılmaktadır. Ambalaj, gidaları koruma fonksiyonunu yerine getirmenin yanında, üzerinde bulunan etiket aracılığıyla gıdanın özellikleri, içeriği ve muhafaza şartları ile ilgili tüketicinin bilgilendirilmesini de sağlamaktadır [15]. Alpuğuz ve ark., [16] tarafından yürütülen araştırmada öğrencilerin \%64.2'si sadece ambalajlı gıdaları tercih ettiğini ifade ederken, öğrencilerin \%5.9'u açıkta satılan gida ürünlerini tercih ettiğini belirtmiştir. Ambalajlı gida ürünlerini tercih etme oranı kız öğrencilerde \%70.1 iken, erkek öğrencilerde \%56.2 olmuştur $(\mathrm{P}<0.05)$ [16]. İncedal Sonkaya ve ark. [17]'nın çalışmasında "Açıkta satılan besinleri alırım." ifadesine "hiç" yanıtını veren yüksekokul öğrencilerinin oranı \%22.3 olarak belirlenmiştir. Diğer öğrenciler "nadiren", "bazen", "sık s1k" veya "her zaman" açıkta satılan besinleri aldığını belirtmiştir [17]. Çalık [18], Eskişehir'de 800 tüketiciyle yürüttüğü araştırmasında tüketicilerin \%41.8'inin "çoğunlukla", \%47.5'inin "sürekli" ambalajlı gida ürünlerini tercih ettiklerini saptamıştır.

Etiket, herhangi bir ürünün kalitesiyle ilgili özelliklerini belirtmek için ambalajın üzerine yazılan grafik ve yazı olarak tanımlanmaktadır [19]. Etiketleme aracılığıyla üretici firma ve ürün ile ilgili bilgiler (firma adı, kalite belgesiyle ilgili bilgiler, ürünün ad, içeriği) belirtilmektedir. Son yıllarda tüketicilerin etiket üzerinde yer alan bilgileri daha dikkatlice izlediği görülmektedir [20]. Etiketler, ürünün menşei, fiyatı, bileşimi, kullanma süresi, son kullanma tarihi ve besleyicilik değeri ile ilgili bilgileri bulundurması nedeniyle tüketicilerin bilinçli bir şekilde sağlıklı olan gıda ürününü seçmesini kolaylaştırmaktadır [21].

Tüketicilerin etiket üzerindeki bilgileri okumalarının satın alma kararlarında oldukça önemli etkisi olmaktadır [22]. Avustralya ve Yeni Zelanda'daki tüketiciler ile yapılmış olan bir çalışmada etiket kullanılmasının tüketicilerin sağlıklı ve bilinçli seçim yapmasında etkili olduğu belirlenmiştir [23]. "Satın aldığım gıda ürünlerinin etiket bilgilerini okurum." ifadesine tüketicilerin \%64.0'ü "kesinlikle katılıyorum" yanıtını vermiştir (Tablo 2). Topuzoğlu ve ark. [14]'nın çalışmasında ise, aynı ifadeye katılan tüketicilerin oranı $\% 52.1$ olarak bulunmuștur.

Alpuğuz ve ark., [16]'nın çalışmasında öğrencilerin ambalajlı gıda alırken dikkat ettikleri hususlar sorulduğunda "son kullanma tarihi"nin işaretlenme oranı \%60.7 olmuştur. Öğrencilerin \%51.3'ü ambalajlı gıda satın alırken etiket bilgilerini "her zaman" okuduklarını ifade etmiş, okumadığını belirten öğrencilerin oranının $(\% 48,7)$ ise, bu değere oldukça yakın olduğu görülmüştür. Etiket bilgilerini okuyan kız öğrencilerin oranı (\%55.8) erkek öğrencilerin oranından (\%45.0) anlamlı derecede yüksek çıkmıştır $(\mathrm{P}<0.05)$ [16]. Onurlubaş ve Gürler [12]'in çalışmasında ambalajın üzerinde ya da etiketinde bulunduğu takdirde "son kullanma tarihi"ni "daima" okuyanların oranı \%53.9, "raf ömrü"nü "daima" okuyanların oranı \%22.2, "fiyat"1 "daima" okuyanların oranı \%53.4 olarak bulunmuştur.

Yaman ve Özgen [24]'in çalışmasında tüketicilerin \%24.3'ünün etiket bilgilerini "her zaman", \%75.7'sinin ise "bazen" okuduğu saptanmıştır. Bu çalışmada, tüketicilerin \%78.4'ünün son kullanma tarihini, \%76.9'unun üretim tarihini, \%57.5'inin fiyatını ve \%49.4'ünün de ambalajlı gıdalarda raf ömrünü "her zaman" okuduklarını belirlediklerini bildirmişlerdir [24]. Yurdagül [25], 523 tüketici ile gerçekleştirdiği çalışmasında tüketicilerin \%66.3'ünün etiket bilgilerini okumadıklarını saptamıştır. 
Tablo 2. Tüketicilerin gıda güvenliği ve gıda hijyeni ile ilgili ifadelere verdikleri yanıtların dağılımı

\begin{tabular}{|c|c|c|c|}
\hline İfadeler & $\begin{array}{c}\text { Kesinlikle } \\
\text { katılıyorum } \\
\text { s (\%) }\end{array}$ & $\begin{array}{c}\text { Kismen } \\
\text { katılıyorum } \\
\text { s }(\%)\end{array}$ & $\begin{array}{c}\text { Kesinlikle } \\
\text { katılmıyorum } \\
\text { s }(\%)\end{array}$ \\
\hline \multicolumn{4}{|l|}{ Gıda ürünü satın almadaki bilinç düzeyleri ile ilgili ifadeler } \\
\hline Satın aldığım gıda ürünlerinin etiket bilgilerini okurum. & $259(64.0)$ & $127(31.4)$ & $19(4.7)$ \\
\hline Gıda ürünlerini satın alırken son kullanma tarihlerine dikkat ederim. & $340(84.0)$ & $60(14.8)$ & $5(1.2)$ \\
\hline Ürünü satın alırken ambalajın sağlam olup olmadığına dikkat ederim. & $325(80.2)$ & $65(16.0)$ & $15(3.7)$ \\
\hline Ambalajın gıda ürününe zarar vermeyecek malzemeden yapılmasına dikkat ederim. & $218(53.8)$ & $148(36.5)$ & $39(9.6)$ \\
\hline Satın aldığım ürünün insan sağlığına olumsuz etkisi olup olmadığına dikkat ederim. & $268(66.2)$ & $117(28.9)$ & $20(4.9)$ \\
\hline $\begin{array}{l}\text { Yiyecek maddelerinin satıldığı yerin koşullarına (temizlik, hijyen, rutubet) dikkat } \\
\text { ederim. }\end{array}$ & $325(80.2)$ & $74(18.3)$ & $6(1.5)$ \\
\hline Açıkta satılan yiyecekleri satın almam. & $183(45.2)$ & $184(45.4)$ & $38(9.4)$ \\
\hline $\begin{array}{l}\text { Dondurulmuş ürün satın alırken çözünmemiş olmasına, içinde buz kristalleri olmamasına } \\
\text { dikkat ederim. }\end{array}$ & $246(60.7)$ & $130(32.1)$ & $29(7.2)$ \\
\hline $\begin{array}{l}\text { Teneke konserve alırken alt ve üst kapakları şişkin olanları, kutusu hasar görmüşleri satın } \\
\text { almam. }\end{array}$ & $329(81.2)$ & $54(13.3)$ & $22(5.4)$ \\
\hline Ambalajsız gıda ürünü alırken tazeliğine, temizliğine dikkat ederim. & $353(87.2)$ & $41(10.1)$ & $11(2.7)$ \\
\hline \multicolumn{4}{|l|}{ Gıda ürünü satın almadaki etkilendikleri faktörler ile ilgili ifadeler } \\
\hline Gıda ürününün fiyatı karar vermemde önemlidir. & $184(45.4)$ & $168(41.5)$ & $53(13.1)$ \\
\hline İndirimli veya promosyonlu olan ürünler satın almamda etkilidir. & $156(38.5)$ & $199(49.1)$ & $50(12.3)$ \\
\hline İnternetten ve medyadan edindiğim bilgiler ürünleri satın almamda etkilidir. & $131(32.3)$ & $180(44.4)$ & $94(23.2)$ \\
\hline \multicolumn{4}{|l|}{$\begin{array}{l}\text { Gıdayı hijyenik şartlarda hazırlama ve saklama konusundaki tutumları ile ilgili } \\
\text { ifadeler }\end{array}$} \\
\hline Ürünleri saklarken ya da pişirirken ambalajdaki talimatlara uyarım. & $233(57.5)$ & $136(33.6)$ & $36(8.9)$ \\
\hline Dondurulmuş gıdayı buzdolabında çözündürürüm. & $125(30.9)$ & $161(39.8)$ & $119(29.4)$ \\
\hline Yemek hazırlamada kullandığım tezgah ve araç-gereçleri dezenfekte ederim. & $284(70.1)$ & $100(24.7)$ & $21(5.2)$ \\
\hline Yemeği karıştırdığım kepçeyle yemeğin tadına bakmam. & $192(47.4)$ & $144(35.6)$ & $69(17.0)$ \\
\hline Çiğ ve pişmiş gıdayı yan yana saklamam. & $258(63.7)$ & $106(26.2)$ & $41(10.1)$ \\
\hline Çiğ ve pişmiş etleri, sebzeleri hazırlarken farklı bıçak ve kesme tahtası kullanırım. & $201(49.6)$ & $136(33.6)$ & $68(16.8)$ \\
\hline Et ürünlerini (tavuk, balık, kırmızı et) pişirinceye kadar buzdolabında saklarım. & $339(83.7)$ & $52(12.8)$ & $14(3.5)$ \\
\hline Yemek hazırlamada bakır veya alüminyum kap kullanmam. & $187(46.2)$ & $161(39.8)$ & $57(14.1)$ \\
\hline Yiyecekleri plastik kaplarda uzun süre bekletmem. & $234(57.8)$ & $134(33.1)$ & $37(9.1)$ \\
\hline Sebze ve meyveleri bol ve temiz su ile yıkarım. & $365(90.1)$ & $30(7.4)$ & $10(2.5)$ \\
\hline Pişmiş yemekleri soğuduktan sonra buzdolabında saklarım, dışarıda bırakmam. & $322(79.5)$ & $66(16.3)$ & $17(4.2)$ \\
\hline Buzdolabından çıkardığım yemeği yemeden önce en az $75^{\circ} \mathrm{C}^{\prime}$ ye kadar ısıtırım. & $147(36.3)$ & $174(43.0)$ & $84(20.7)$ \\
\hline $\begin{array}{l}\text { Yemekleri pişirirken ya da tekrar isıtırken uygun sıcaklıkta olduğunu anlamak için } \\
\text { termometre kullanırım. }\end{array}$ & $61(15.1)$ & $62(15.3)$ & $282(69.6)$ \\
\hline \multicolumn{4}{|l|}{ Gıda güvenliği ile ilgili konulardaki bilgi düzeyleri ve davranışları ile ilgili ifadeler } \\
\hline Gıda ürünlerinin ambalajı üzerinde beslenmeyle ilgili daha fazla bilgi olmasını isterim. & $288(71.1)$ & $100(24.7)$ & $17(4.2)$ \\
\hline Dengeli öğ̈̈nler hazırlamaya gayret ederim. & $204(50.4)$ & $165(40.7)$ & $36(8.9)$ \\
\hline $\begin{array}{l}\text { Yiyeceklerin protein ve vitamin içeriklerini bilirim, bilmediklerimi öğrenmeye gayret } \\
\text { ederim. }\end{array}$ & $168(41.5)$ & $171(42.2)$ & $66(16.3)$ \\
\hline $\begin{array}{l}\text { Yiyecekleri yıkamada veya yemek hazırlamada kullandığım suyun temizliğine dikkat } \\
\text { ederim. }\end{array}$ & $340(84.0)$ & $51(12.6)$ & $14(3.5)$ \\
\hline Deterjan ve dezenfektanları mutfakta saklamam. & $168(41.5)$ & $175(43.2)$ & $62(15.3)$ \\
\hline Satın aldığım bir ürün bozuksa iade ederim. & $289(71.4)$ & $94(23.2)$ & $22(5.4)$ \\
\hline Gıda ürünlerinde katkı maddesi kullanılmaması önemlidir. & $329(81.2)$ & $66(16.3)$ & $10(2.5)$ \\
\hline Ürünün lezzetinden çok besleyici olması önemlidir. & $209(51.6)$ & $166(41.0)$ & $30(7.4)$ \\
\hline Besin değeri iyi olan gıdalar daha pahalıdır. & $182(44.9)$ & $153(37.8)$ & $70(17.3)$ \\
\hline Hormonsuz gida ürünleri için fazla para öderim. & $199(49.1)$ & $152(37.5)$ & $54(13.3)$ \\
\hline Kaliteli ve güvenilir gıda ürünleri kolay bulunabilir. & $106(26.2)$ & $164(40.5)$ & $135(33.3)$ \\
\hline Markalı ürünler her zaman kaliteli ve güvenilirdir. & $94(23.2)$ & $202(49.9)$ & $109(26.9)$ \\
\hline Büyük market ve alışveriş merkezlerinde satılan gıda ürünleri kalitelidir. & $87(21.5)$ & $213(52.6)$ & $105(25.9)$ \\
\hline Reklamlar ürün hakkında gerekli bilgileri verir. & $77(19.0)$ & $143(35.3)$ & $185(45.7)$ \\
\hline
\end{tabular}

Sağlık [26]'ın yürütmüş olduğu araştırmada tüketicilerin \%75'inin etiket bilgilerini "kısmen" okuduğu, \%25'inin "hiçbir zaman" okumadıkları belirlenmiştir. Purutcuoğlu ve Bayraktar [27], gerçekleştirdikleri çalışmada lise öğrencilerinin ambalajlı gıda ürünlerinde son kullanma tarihini ve üretim tarihini okuduklarını tespit etmiştir. Baysan [28]'ın çalışmasında etiket bilgilerini okumayı onaylayan tüketicilerin oranı \%79.3 iken, son kullanma tarihine dikkat etme \%94.3 oranında onaylanmıştır.

İncedal Sonkaya ve ark. [17]'nın çalışmasında “Ambalajlı ürün alırken etiket bilgilerini okur musunuz?" sorusuna yüksekokul öğrencilerinin \%19.6's1 “sık s1k", \%18.3'ü “daima” yanıtını vermiştir. Salicik ve Yıldırım Kumral [29]'ın çalışmasında etiket bilgisini okuyan tüketicilerin oranı \%76.0 iken, 
satın alma sırasında son kullanma tarihi en önemli (\%30) etiket bilgisi olarak ifade edilmiştir. Daha önce yapılan birçok araştırmanın sonuçlarına göre de gıda ürünü satın almada dikkat edilen en önemli kriterin son kullanma tarihi olduğu belirlenmiştir [12, 30-32, 34]. Çalık [18]'1n yürüttüğü araştırmanın bulgularına göre tüketicilerin \%24.6'sının "çoğunlukla", \%46.5'inin ise "her zaman" son kullanım tarihine dikkat ettikleri tespit edilmiştir. Schucker ve ark. [34] tüketicilerin satın alma tutumlarını inceledikleri, 2 yıl süren araştırmaları sonucunda aile fertlerinden birinin özel bir diyet uyguladığı müşteriler (\%62) arasında ve 25 yaş altı gençlerde (\%52) etiket okuma alışkanlığının yaygın olduğu gözlemlenmiştir. Yiyeceklerin üzerinde bulunan etiketlerin süpermarketten alışveriş yapan tüketicilerin satın alma tutumlarını etkilediği ve onları bazı ürün kategorilerinde daha sağlıklı seçimlere yönelttiği belirlenmiştir [34].

Mitchel ve ark. [35] Kuzey Virjinya'da kadınlarla gerçekleştirdikleri çalışmada gıda ürünü satın alırken katılımciların \%31'inin "bazen", \%58.0'inin "hemen hemen her zaman" yiyeceklerin etiket bilgisini okudukları saptanmıştır. Şanlıer ve Şeren [36] tarafından Ankara'daki değişik semtlerde bulunan süpermarketlerden alışveriş yapan 185 tüketici ile yapılan çalışmada, gıda ambalajı üzerindeki etiket bilgilerini tüketicilerin \%39.4'ünün "bazen", üretim tarihini ise tüketicilerin \%60.0'ının "her zaman" okuduğu belirlenmiştir. Akdevelioğlu ve ark. [37]'nın çalışmasında üniversite öğrencilerinin \%46.6'sının ambalajlı gıda satın alırken son kullanma tarihini "daima" okuduğu saptanmıştır.

Özgül ve Aksulu [20]'nun İzmir ilinde yürüttükleri çalışmada, son kullanma tarihi ve üretim tarihinin en önemli bilgi olma özelliğini korudukları belirlenmiştir. Aras Okumuş ve Bulduk [38] tarafından Konya ilinin merkezindeki tüketicilerle gerçekleştirilen araştırmada, gıda ürünü satın alırken tüketicilerin en fazla son kullanma tarihini okudukları, ikinci olarak sağlığa uygun olup olmadığına dikkat ettikleri saptanmıştır. Yılmaz ve ark. [39] tarafından Trakya Bölgesinde yaşayan tüketici ailelerle yürütülen araştırmada ailelerin gıda alırken etiket üzerindeki bilgilerden öncelikle üretim tarihine ve son kullanma tarihine dikkat ettikleri belirlenmiştir.

Ankara ilinde 324 tüketiciyle Albayrak [40] tarafından yapılan anket çalışması sonucunda, gıda maddeleri satın alırken, tüketicilerin en çok dikkat ettikleri etkenlerin gıda ürününün ambalajı, üretim ve son kullanma tarihi olduğu belirtilmiştir. Uzunöz ve ark. [41]'nın araştırmasında ise satın aldıkları ürünlerin son kullanma tarihine dikkat eden katılımcıların oranının \%90.47 olduğu tespit edilmiştir. Gözener ve ark. [42]'nın yürüttüğü araştırmada öğrencilerin \%90.38'inin gıda etiketlerinde öncelikle son kullanma tarihine dikkat ettiği, üretim tarihine dikkat edenlerin oranının \%45.67, içindekiler kısmına dikkat edenlerin oranı \%45.19, logolara dikkat edenlerin oranı \% 12.98 , ağırlığına dikkat edenlerin oranı ise \%9.13 olduğu belirlenmiştir. Kılıç [31] tarafından gerçekleştirilen çalışmada gıda satın alırken son kullanma tarihine dikkat eden tüketicilerin oranının \%22.0 olduğu ortaya konmuştur. İncedal Sonkaya ve ark. [17]'nın çalışmasında gıda alışverişinde son kullanma tarihine dikkat etmenin "önemli" ve "oldukça önemli" olduğunu belirten yüksekokul öğrencilerinin oranı sırasıyla; \%16.8 ve \%79.6 olarak bulunmuştur.

"Ürün satın alırken ambalajın sağlam olup olmadığına dikkat ederim." ifadesine tüketicilerin \%80.2'si "kesinlikle katılıyorum" yanıtını vermiştir (Tablo 2). Onurlubaş ve Gürler [12]'in araştırmasında "gıda ürünlerinin ambalajının sağlamlığını kontrol etmek" tutumunun tüketicilerin \%50.4'ü için “çok önemli” olduğu görülmüştür. Topuzoğlu ve ark. [14]'nın araştırmasında satın almada gıda ürününün ambalajının sağlamlığına dikkat etme tutumu, katılımcıların en fazla (\%92.8) önemsediği tutum olarak ortaya çıkmıştır. Baysan [28]'ın çalışmasında katılımcıların \%95.5'i ürün alırken ambalajın sağlamlığını dikkat etme tutumuna katıldığını belirtmiştir. İncedal Sonkaya ve ark. [17]'nın çalışmasında "Besinleri satın alırken ambalajının bozulmamış-yırtılmamış olmasına dikkat ederim." ifadesine "sık sık" ve "her zaman" yanıtını veren yüksekokul öğrencilerinin oranı sırasıyla; \%23.4 ve $\% 61.7$ olarak belirlenmiştir.

Albayrak [40]'ın araştırmasında tüketicilerin gıda ambalajının geri dönüşümlü olup olmadığına, ambalajın kalitesine ve ambalaj malzemesinin cinsine dikkat ettikleri tespit edilmiştir. Bizim çalışmamızda da "Ambalajın gıda ürününe zarar vermeyecek malzemeden yapılmasına dikkat ederim." ifadesine kesinlikle katılan tüketicilerin oranı \%53.8 olmuştur. Topuzoğlu ve ark. [14]'nın çalışmasında aynı ifadeye katılan tüketicilerin oranı \%64.7 olarak bulunmuştur. Baysan [28]'ın çalışmasında katılımcıların ambalajın gıda ürününe zarar vermeyecek maddeden yapılması faktörüne dikkat etme tutumuna bakıldığında \%76.7'sinin buna dikkat ettiği görülmüştür.

"Satın aldığım ürünün insan sağlığına olumsuz etkisi olup olmadığına dikkat ederim" ifadesine tüketicilerin \%66.2'si "kesinlikle katılıyorum", \%28.9'u "kısmen katılıyorum” yanıtını vermiş̧tir (Tablo 
2). Topuzoğlu ve ark. [14]'nın çalışmasında aynı ifadeye katılan tüketicilerin oranı \%51.8 olarak bulunmuştur. Onurlubaş ve Gürler [12]'in araştırmasında "Gıda ürünlerinde kullanılan ambalajların sağlığa zararlı olmaması" tutumunun tüketicilerin \%66.6's1 için “çok önemli”, \%28.7'si için "önemli”" olduğu görülmüştür.

Gülse Bal ve ark. [43]'nın çalışmasında Tokat ilindeki tüketicilere gıda ürünü satın alırken öncelikli olarak dikkat ettikleri özellikler sorulduğunda, tüketicilerin \%86.36'sının birinci tercihinin ürünün sağlık açısından güvenli oluşu olduğu tespit edilmiştir. Onurlubaş ve Gürler [12]'in çalışmasında "Satın aldığınız ürünlerin sağlık riskini göz önünde bulundurma" tutumunun tüketicilerin \%53.9'u için “çok önemli”, \%36.2'si için “önemli” olduğu görülmüştür.

"Yiyecek maddelerinin satıldığı yerin koşullarına (temizlik, hijyen, rutubet) dikkat ederim." ifadesine kesinlikle katıldığını belirten tüketicilerin oranı \%80.2 iken (Tablo 2), Topuzoğlu ve ark. [14]'nın çalışmasında aynı ifadeye katılan tüketicilerin oranı \%92.2 olarak bulunmuştur. Salicik ve Yıldırım Kumral [29]'ın çalışmasında "Yiyecek maddelerinin satıldığı yerin hijyen koşulları çok önemlidir." ifadesine "katıllyorum" diyenlerin oran1 \%95.0 olarak bulunmuştur.

Topuzoğlu ve ark. [14]'nın çalışmasında, tüketicilerin büyük çoğunluğunun gıda maddelerinin üretildiği yerlerin hijyeni ve temizliği, yiyecek maddelerinin satıldığı yerin koşulları, ürün ambalajının sağlam olup olmaması, fiyat, lezzet gibi faktörlere dikkat edildiği ve önem verildiği tespit edilmiştir [14].

Modjuszka ve Caswell [44] gida ürünlerinde tüketici tercihlerini ve tüketicilerin beslenme bilgisini sorguladıkları çalışmada etiket ve beslenme bilgisi kullanımının talebi önemli derecede etkilemediği sonucuna ulaşılmıştır.

Kızılaslan ve Kızılaslan [45]'ın Tokat ilindeki tüketicilerle yürüttüğü çalışmasında gıda ürünü satın alma aşamasında tüketicilerin marka, ambalaj, satış ve üretim yeri hijyeni, üretim ve son kullanma tarihi, besin değeri, besleyicilik, doyuruculuk, sağlıklı olma faktörlerini öncelikle göz önünde bulundurdukları tespit edilmiştir. Üniversite öğrencilerinin gıda ürünlerindeki etiket ile ilgili tutumlarının incelendiği, Çınar ve Özer [46]'in çalışmasında öğrencilerin en çok son kullanma tarihine ve imal tarihine, ikinci olarak fiyatına, üçüncü sırada ürünün içeriği ile ilgili bilgilere ve en son olarak kullanım şartlarına dikkat ettikleri saptanmıştır.

Tüketicilerin gıda ürünü satın almadaki etkilendikleri faktörler ile ilgili ifadelere verdikleri yanıtlar incelendiğinde; "İnternetten ve medyadan edindiğim bilgiler ürünleri satın almamda etkilidir." ifadesine; \%32.3'ü kesinlikle katıldığını, \%44.4'ü kısmen katıldığını, \%23.2'si kesinlikle katılmadığını ifade etmiştir (Tablo 2).

Alpuğuz ve ark. [16]'nın çalışmasında gıda ürünü satın almada reklamlardan etkilendiğini dile getiren öğrencilerin oranı \%0.4 olarak tespit edilirken, Demirağ ve ark. [47]'nın araştırmasında gıda ürünü satın almada reklamlardan etkilendiğini belirten tüketicilerin oranı \%45 olarak bulunmuştur. Araştırıcılar tüketicilerin yaşları ve eğitim düzeyinin artması ile birlikte gıda reklamlarını inandırıcı bulma oranının giderek düştüğünü saptamışlardır [49]. Onurlubaş ve Gürler [12]'in çalışmasında gıda satın almada etkilenilen araçlar arasında "televizyon reklamları" \%62.7 ile en çok işaretlenme oranına sahip olmuştur. "İndirim günleri"nin işaretlenme oranı \%53.4, "promosyonlu satışlar"'n işaretlenme oranı \%42.1, "internet reklamları"nın işaretlenme oranı \%12.7 olarak tespit edilmiştir. Aynı çalışmada "promosyon, ürün kampanyaları gibi satış arttırıcı kampanyalar"ın tüketicilerin \%30.4'ü için "çok önemli”, \%36.7'si için “önemli” olduğu saptanmıştır.

Kolodinsky ve ark. [48] tarafından 110 üniversite öğrencisi ile yürütülen araştırmada, gıda satın alma davranışlarında fiyatın etkili olduğu tespit edilmiştir. Bizim çalışmamızda "Gıda ürününün fiyatı karar vermemde önemlidir." ifadesine tüketicilerin \%45.4'ü "kesinlikle kat1lyorum", \%13.1'i ise "kesinlikle katılmıyorum" yanıtını vermiştir (Tablo 2). Salicik ve Yıldırım Kumral [29]'ın çalışmasında "Satın alacağım ürünlerin fiyatı karar vermemde etkilidir." ifadesine evet diyen tüketicilerin oranı $\% 58.0$ olarak bulunmuştur. Gülse Bal ve ark. [43]'nın çalışmasında Tokat ilindeki tüketicilerin \%15.65'inin gıda ürününü satın alırken öncelikle ürünün fiyatına baktığı tespit edilmiştir. Onurlubaş ve ark. [49]'nın yaptığı çalışmada, tüketicilerin alışveriş yaparken fiyat araştırması yaptığı ve fiyatın en uygun olduğu yerden alışveriş yaptığ belirlenmiştir.

Salicik ve Yıldırım Kumral [29]'ın çalışmasında, gıda ürünü satın alınırken dikkat edilen en önemli tercih nedeni öncelikli olarak tazelik (\%21), daha sonra fiyat (\%16) ve ambalaj (\%13) olmuştur. Farklı çalışmalarda ise doğallık ve tazelik en önemli kriter olarak tespit edilirken, gelir düzeyine bağlı olarak fiyatın ikinci önemli kriter olduğu belirlenmiştir [33, 41, 39]. Onurlubaş ve Gürler [12]'in 
çalışmasında "gıda ürünlerini satın alırken düşük fiyatlı olması"nın tüketicilerin \%20.9'u için “çok önemli”, \%25.4'ü için “önemli” olduğu saptanmıştır. İncedal Sonkaya ve ark. [16]'nın çalışmasında "gıda alışverişinde fiyata dikkat etme"nin "önemli" ve "oldukça önemli" olduğunu belirten yüksekokul ögrencilerinin oranı sırasıyla; \%27.9 ve \%63.2 olarak belirlenmiştir. Mojduska ve Caswell [44] gıda ürünlerinde tüketici tercihlerini ve tüketicilerin beslenme bilgisini sorguladıkları çalışmada reklam, indirimler, damak zevkleri ve fiyatın talepte önemli etkiye sahip olduğu ortaya konulmuştur.

Tüketicilerin gıdayı hijyenik şartlarda hazırlama ve saklama konusundaki tutumları ile ilgili ifadelere verdikleri yanıtlara bakıldığında; "Dondurulmuş gıdayı buzdolabında çözündürürüm." ifadesine; \%39.8'i kısmen katılmış, \%29.4'ü kesinlikle katılmamıştır. "Çiğ ve pişmiş etleri, sebzeleri hazırlarken farklı bıçak ve kesme tahtası kullanırım." ifadesine; tüketicilerin \%49.6'sının "kesinlikle kat1lıyorum", \%33.6'sinın "kısmen katılıyorum", \%16.8'sinin "kesinlikle kat1lmıyorum" yanıtını verdiği tespit edilmiştir. "Yemekleri pişirirken ya da tekrar 1sitırken uygun sıcaklıkta olduğunu anlamak için termometre kullanırım.” ifadesine; tüketicilerin \%15.1'i kesinlikle katıldığını, \%15.3'ü kısmen katıldığını, \%69.6'sı kesinlikle katılmadığını belirtmiştir (Tablo 2).

Salicik ve Yıldırım Kumral [29]'ın çalışmasında "Et için kullandığım tahtada sebze-meyve de keserim." ifadesine "evet" diyenlerin oranı \% 49.0 olarak ve "Çiğ yiyecekler için kullanılan bıçak, tahta pişmiş yiyecekler için kullanılabilir." ifadesine evet diyenlerin oranı \%23.0 olarak belirlenmiştir.

"Çiğ ve pişmiş gıdayı yan yana saklamam." ifadesine kesinlikle katıldığını belirten tüketicilerin oranının \%63.7 olması (Tablo 2), Salicik ve Yıldırım Kumral [29]'ın çalışmasında "Pişmiş yiyeceklerle pişmemişlerin temas etmemesini sağlarım." ifadesine "evet" diyenlerin oranının \%70.0 olarak bulunmasıyla benzerdir. İncedal Sonkaya ve ark. [17]'nın çalışmasında "Çiğ besinlerle pişmiş besinlerin temasını engelleyecek şekilde dolaba yerleştiririm." ifadesine "sık sık" ve "her zaman" yanıtını veren yüksekokul öğrencilerinin oranı sırasıyla; \%21.5 ve \%40.2 olarak belirlenmiştir.

"Pişmiş yemekleri soğuduktan sonra buzdolabında saklarım, dışarıda bırakmam." ifadesine "kesinlikle katılıyorum" yanıtını veren tüketicilerin oranı \%79.5 olarak saptanmıştır (Tablo 2). Salicik ve Yıldırım Kumral [29]'ın çalışmasında ise; "Sıcak yemekleri soğumasını beklemeden buzdolabına koyarım." ifadesine "hayır" diyenlerin oranı \%85 olarak tespit edilmesi çalışmamızın ilgili sonucuyla oldukça benzer bulunmuştur.

"Dondurulmuş gıdayı buzdolabında çözündürürüm." ifadesine kesinlikle katılıyorum yanıtını verenlerin oranı \%30.9 (Tablo 2) iken, Salicik ve Yıldırım Kumral [30]'ın çalışmasında "Dondurulmuş et oda sıcaklığında çözündürülebilir." ifadesine "evet" diyenlerin oranı \%64.0 olarak tespit edilmiştir. Jay ve ark. [50] Avusturya'da yaptıkları çalışmada katılımcıların \%40.0'ının eti oda sıcaklığında çözdürdüklerini tespit etmişlerdir.

"Ürünleri saklarken ya da pişirirken ambalajdaki talimatlara uyarım." ifadesine "kesinlikle katılıyorum" yanıtını veren tüketicilerin oranının \%57.5 olduğu saptanmıştır (Tablo 2). Topuzoğlu ve ark. [14]'nın çalışmasında aynı ifadeye katılan tüketicilerin oranı \%67.1 olarak bulunmuştur. Akdevelioğlu ve ark. [37]'nın çalışmasında ise üniversite öğrencilerinin \%36.5'inin gıda ambalajlarındaki kullanma ve saklama koşulların "daima" okuduğu belirlenmiştir. Onurlubaş ve Gürler [12]'in çalışmasında ambalajın üzerinde ya da etiketinde bulunduğu takdirde "buz çözdürme talimatı"nı "daima" okuyanların oranı \%11.0, "pişirme talimatı"nı "daima" okuyanların oranı \%20.0, "saklama talimatı"nı "daima" okuyanların oranı \%26.9 olarak bulunmuştur. Aynı çalışmada "Gıda ürünlerini talimatlara uygun şekilde pişirip saklanması" tutumunun tüketicilerin \%36.9'u için "çok önemli", \%47.7'si için ise "önemli" olduğu belirlenmiştir. Baysan [28]'ın çalışmasında ürünleri saklarken veya pişirirken gıdanın ambalajı üzerinde yer alan talimata göre hareket etme tutumuna katılımcıların $\% 86.7$ 'sinin katıldığı görülmektedir.

Tüketicilerin gıda güvenliği ile ilgili konulardaki bilgi düzeyleri ve davranışları ile ilgili ifadeler incelendiğinde; "Yiyecekleri yıkamada veya yemek hazırlamada kullandığım suyun temizliğine dikkat ederim." ifadesine; \%84.0'ü kesinlikle katılırken, \%12.6'sı kısmen katılmış, \%3.5'i kesinlikle katılmamıştır. "Gıda ürünlerinde katkı maddesi kullanılmaması önemlidir." ifadesine; tüketicilerin \%81.2'si "kesinlikle katılıyorum", \%16.3'ü "kismen kat1lyorum", \%2.5'i oranında "kesinlikle katılmıyorum" yanıtını vermiştir (Tablo 2). Topuzoğlu ve ark. [14]'nın çalışmasında aynı ifadeye katılan tüketicilerin oranı \%77.2 olarak bulunmuştur. Baysan [28]'ın çalışmasında hemşirelerin \%86.0'sının aynı ifadeye katıldığı veya kesinlikle katıldığı görülmüştür.

Tüketicilerin \%19.0'u "Reklamlar ürün hakkında gerekli bilgileri verir." ifadesine kesinlikle katıldığını, \%35.3'ü kısmen katıldığını, \%45.7'si kesinlikle katılmadığını dile getirmiştir (Tablo 2). 
Topuzoğlu ve ark. [14]'nın çalışmasında aynı ifadeye katılan tüketicilerin oranı \%18.0 olarak bulunmuştur.

"Yiyeceklerin protein ve vitamin içeriklerini bilirim, bilmediklerimi öğrenmeye gayret ederim." ifadesine tüketicilerin \%41.5'i "kesinlikle katılıyorum" yanıtını verirken, Topuzoğlu ve ark. [14]'nın çalışmasında aynı ifadeye katılan tüketicilerin oranının \%52.7 olduğu ortaya çıkmıştır. Onurlubaş ve Gürler [12]'in çalışmasında etiketteki "yağ-protein içeriği”"ni "daima” okuduğunu belirten tüketicilerin oranı \%19.5, "vitamin veya mineral içeriği"ni "daima" okuduğunu belirten tüketicilerin oranı \%12.7 olarak tespit edilmiştir.

Salicik ve Yıldırım Kumral [29]'ın çalışmasında “Gıda ürünlerinde katkı maddesi kullanılması önemlidir." ifadesine tüketicilerin \%72.0'si "katılmıorum" yanıtını vermiştir.

"Markalı ürünler her zaman kaliteli ve güvenilirdir." ifadesine tüketicilerin \%26.9'u "kesinlikle katılmıyorum" şeklinde yanıt vermiştir (Tablo 2). "Markalı ürünler her zaman güvenlidir." ifadesine Salicik ve Yıldırım Kumral [29]'ın çalışmasında "katılıyorum" yanıtını veren tüketicilerin oranı \%28.0, "Markalı ürünler her zaman kalitelidir." ifadesine Topuzoğlu ve ark. [14]'nın çalışmasında katılan tüketicilerin oranı \%55.7 olarak saptanmıştır. Gülse Bal ve ark. [43]'nın çalışmasında ise Tokat ilindeki tüketicilerin \%16.16'sının bir gıda ürününü alırken öncelikle markasına baktığı belirlenmiştir.

Alpuğuz ve ark. [16]'nın çalışmasında ambalajlı gıdalardaki etiket bilgilerini yetersiz bulan öğrencilerin oranı \%24.3, Albayrak [40]'ın araştırması kapsamında ambalajlı gıdalardaki etiket bilgilerini yetersiz bulan tüketicilerin oranı \%37.7, İncedal Sonkaya ve ark. [17]'nın çalışmasında etikette yazılan bilgileri yüksekokul öğrencilerinin \%7.7'si "hiç" yeterli bulmazken, bizim çalışmamızda "Gıda ürünlerinin ambalajı üzerinde beslenmeyle ilgili daha fazla bilgi olmasını isterim." ifadesine katılan tüketicilerin oranı \%71.1 olarak bulunmuştur (Tablo 2).

"Hormonsuz gıda ürünleri için fazla para öderim." ifadesine kesinlikle katılan tüketicilerin oranı \%49.1, kısmen katılan tüketicilerin oranı \%37.5 (Tablo 2) iken, Topuzoğlu ve ark. [14]'nın çalışmasında aynı ifadeye katılan tüketicilerin oranı \%67.1 olarak bulunmuştur. Baysan [28]'ın çalışmasında hemşirelerin \%23.0'ü hormonsuz ürünlere fazladan ödeme yapmaya razı olmayacağını belirtmiştir. Salicik ve Yıldırım Kumral [29]'ın çalışmasında "Hormonsuz gıda ürünlerini almaya dikkat ederim." ifadesine "evet" diyenlerin oranı \%80.0 olarak saptanmıştır.

"Büyük market ve alışveriş merkezlerinde satılan gıda ürünleri kalitelidir." ifadesine tüketicilerin \%25.9'u "kesinlikle katılmıyorum" yanıtını verirken, \%52.6's1 kısmen katıldığını belirtmiştir (Tablo 2). Topuzoğlu ve ark. [14]'nın çalışmasında aynı ifadeye katılan tüketicilerin oranı \%46.7 olarak bulunmuştur. Salicik ve Yıldırım Kumral [29]'ın çalışmasında "Büyük market ve AVM'lerde satılan gıda ürünleri güvenlidir." ifadesine tüketicilerin \%27.0'si "katıllyorum", \%43.0'ü ise "kararsızım" yanıtını vermiştir. Bruhn ve Scutz [51]'un gerçekleştirdiği araştırmada Kaliforniya'lı tüketicilerin \%17.0'si süpermarketlerden alınan gıda ürünlerini "tamamen", \%69.0'u ise "oldukça" güvenilir olarak bulmuştur.

"Satın aldığım bir ürün bozuksa iade ederim." ifadesine tüketicilerin \%71.4’ü "kesinlikle katılıyorum" yanıtını vermiştir (Tablo 2). Topuzoğlu ve ark. [14]'nın çalışmasında aynı ifadeye katılan tüketicilerin oranı \%83.2 olarak bulunmuştur. Baysan [28]'ın çalışmasında hemşirelerin \%22.3'ünün bozuk ürünü iade etme tutumunu göstermediği ortaya çıkmıştır. Salicik ve Yıldırım Kumral [29]'ın çalışmasında tüketicilerin \%66.0'sı alınan ürün bozuksa ürünü iade etmeyi, \%73.0'ü ise evde bozulmuşsa kullanmadan atmayı tercih etmiştir.

"Ürünün lezzetinden çok besleyici olması önemlidir." ifadesine tüketicilerin \%51.6's1 "kesinlikle katılıyorum”, \%41.0'i “kısmen katılıyorum” yanıtını vermiştir. Topuzoğlu ve ark. [14]'nın çalışmasında "Yiyeceklerin lezzetinden çok besleyici olması önemlidir." ifadesine katılan tüketicilerin oranı \%71.9 olarak bulunmuştur. Baysan [28]'ın çalışmasında katılımcıların \%76.4'ü yiyeceklerin daha çok besleyici olmasını ön planda tutmuştur. Onurlubaş ve Gürler [12]'in araştırmasında "gıda ürünleri alırken lezzetli olması" tüketiciler tarafından \%41.4 oranında "çok önemli", \%46.1 oranında "önemli" olarak kabul edilmiştir. Aynı çalışmada "satın aldığınız gıda ürünlerinin besinsel değeri”nin tüketicilerin \%59.1'i için "çok önemli”, \%34.2'si için "önemli" olduğu belirlenmiştir [12].

Ukraynalı tüketiciler ile gerçekleştirilen sağliklı beslenmeyle ilgili tutumların incelendiği bir araştırmada ise tüketicilerin fazla kalite ve tazeliğe önem verdikleri, bunların ardından gıda ürününün lezzetine ve fiyatına dikkat ettikleri tespit edilmiştir [52]. Mitchel ve ark. [35] tarafindan gerçekleştirilen çalışmada alışveriş yapan kadın katılımcıların \%75'i gıda ürünü satın alma aşamasında lezzet faktörünü "en önemli" olarak belirtmiş, bunun yanında ürünün sağlıklı olmasının ve beslenme bilgisinin de 
“önemli” olduğunu ifade etmişlerdir. Baysan [28]'ın çalışmasında katılımcıların \%97.0'si yiyecek bir ürün satın alırken öncelikli olarak yiyecek maddesinin lezzetli olmasını tercih etmişlerdir.

İncedal Sonkaya ve ark. [17]'nın çalışmasında gıda alışverişinde tadı ve lezzetine dikkat etmenin "önemli" ve "oldukça önemli" olduğunu belirten yüksekokul öğrencilerinin oranı sirasıyla; \%25.1 ve \%73.0, besin değerine dikkat etmenin "önemli" ve "oldukça önemli" olduğunu belirten yüksekokul öğrencilerinin oranı sırasıyla; \%39.1 ve \%36.4 olarak bulunmuştur.

Tüketicilerin 1. (8., 9. ve 10. ifadeler), 3. (14., 18. ve 26. ifadeler) ve 4. (30., 34. ve 36. ifadeler) faktörlere verdikleri yanıtların cinsiyete göre değişimi Tablo 3 'te verilmiştir.

Tablo 3. Tüketicilerin 1. (8., 9. ve 10. ifadeler), 3. (14., 18. ve 26. ifadeler) ve 4. (30., 34. ve 36. ifadeler) faktörlere verdikleri yanıtların cinsiyete göre değişimi $(\mathrm{P}<0.05)$

\begin{tabular}{|c|c|c|c|c|}
\hline Ífadeler & Cinsiyet & $\begin{array}{c}\text { Kesinlikle } \\
\text { katılıyorum } \\
\text { s (\%) }\end{array}$ & $\begin{array}{c}\text { Kısmen } \\
\text { katılıyorum } \\
\text { s }(\%)\end{array}$ & $\begin{array}{c}\text { Kesinlikle } \\
\text { katılmıyorum } \\
\text { s (\%) }\end{array}$ \\
\hline \multicolumn{5}{|l|}{ Gıda ürünü satın almadaki bilinç düzeyleri ile ilgili ifadeler } \\
\hline \multirow{2}{*}{$\begin{array}{l}\text { Dondurulmuş ürün satın alırken çözünmemiş olmasına, içinde } \\
\text { buz kristalleri olmamasına dikkat ederim. }\end{array}$} & Kadın & $144(66.4)$ & $58(26.7)$ & $15(6.9)$ \\
\hline & Erkek & $102(54.3)$ & $72(38.3)$ & $14(7.4)$ \\
\hline \multirow{2}{*}{$\begin{array}{l}\text { Teneke konserve alırken alt ve üst kapakları şişkin olanları, } \\
\text { kutusu hasar görmüşleri satın almam. }\end{array}$} & Kadın & $186(85.7)$ & $26(12.0)$ & $5(2.3)$ \\
\hline & Erkek & $143(76.1)$ & $28(14.9)$ & $17(9.0)$ \\
\hline \multirow{2}{*}{$\begin{array}{l}\text { Ambalajsız gıda ürünü alırken tazeliğine, temizliğine dikkat } \\
\text { ederim. }\end{array}$} & Kadın & $200(92.2)$ & $15(6.9)$ & $2(0.9)$ \\
\hline & Erkek & $153(81.4)$ & $26(13.8)$ & $9(4.8)$ \\
\hline \multicolumn{5}{|l|}{$\begin{array}{l}\text { Gıdayı hijyenik şartlarda hazırlama ve saklama konusundaki } \\
\text { tutumları ile ilgili ifadeler }\end{array}$} \\
\hline \multirow{2}{*}{$\begin{array}{l}\text { Ürünleri saklarken ya da pişirirken ambalajdaki talimatlara } \\
\text { uyarım. }\end{array}$} & Kadın & $137(63.1)$ & $61(28.1)$ & $19(8.8)$ \\
\hline & Erkek & $96(51.1)$ & $75(39.9)$ & $17(9.0)$ \\
\hline \multirow{2}{*}{ Çiğ ve pişmiş gıdayı yan yana saklamam. } & Kadın & $158(72.8)$ & $45(20.7)$ & $14(6.5)$ \\
\hline & Erkek & $100(53.2)$ & $61(32.4)$ & $27(14.4)$ \\
\hline \multirow{2}{*}{$\begin{array}{l}\text { Yemekleri pişirirken ya da tekrar 1sıtırken uygun sıcaklıkta } \\
\text { olduğunu anlamak için termometre kullanırım. }\end{array}$} & Kadın & $28(12.9)$ & $22(10.1)$ & $167(77.0)$ \\
\hline & Erkek & $33(17.6)$ & $40(21.3)$ & $115(61.2)$ \\
\hline \multicolumn{5}{|l|}{$\begin{array}{l}\text { Gıda güvenliği ile ilgili konulardaki bilgi düzeyleri ve } \\
\text { davranışları ile ilgili ifadeler }\end{array}$} \\
\hline \multirow{2}{*}{$\begin{array}{l}\text { Yiyecekleri yıkamada veya yemek hazırlamada kullandığım } \\
\text { suyun temizliğine dikkat ederim. }\end{array}$} & Kadın & $193(88.9)$ & $19(8.8)$ & $5(2.3)$ \\
\hline & Erkek & $147(78.2)$ & $32(17.0)$ & $9(4.8)$ \\
\hline \multirow{2}{*}{ Ürünün lezzetinden çok besleyici olması önemlidir. } & Kadın & $108(49.8)$ & $101(46.5)$ & $8(3.7)$ \\
\hline & Erkek & $101(53.7)$ & $65(34.6)$ & $22(11.7)$ \\
\hline \multirow{2}{*}{ Hormonsuz gıda ürünleri için fazla para öderim. } & Kadın & $91(41.9)$ & $90(41.5)$ & $36(16.6)$ \\
\hline & Erkek & $102(54.3)$ & $72(38.3)$ & $14(7.4)$ \\
\hline
\end{tabular}

Cinsiyete göre, tüketicilerin gıda ürünü satın almadaki bilinç düzeyleri ile ilgili ifadelere verdikleri yanıtlara bakıldığında; "Ambalajsız gıda ürünü alırken tazeliğine, temizliğine dikkat ederim." ifadesine kadınların \%92.2'sinin "kesinlikle kat1lıyorum", \%6.9'unun "kısmen katıliyorum", \%0.9'unun "kesinlikle katılmıyorum" cevabını verdiği saptanmıştır. Erkeklerin ise \%81.4'ü kesinlikle katıldığını, \%13.8'i kısmen katıldığını, \%4.8'i kesinlikle katılmadığını belirtmiştir ( $\mathrm{P}<0.05)$ (Tablo 3).

Sağlık [26]'ın çalışmasında etiket bilgilerini okuma ile cinsiyet arasında ilişki olduğu tespit edilmiş ve etiket bilgilerini okuyan kadınların oranının erkeklerden daha çok olduğu saptanırken, bizim çalışmamızda "Satın aldığım gıda ürünlerinin etiket bilgilerini okurum." ifadesine verilen yanıtlar ile cinsiyet arasındaki farkın anlamlı olmadığı $(\mathrm{P}>0.05)$ görüldüğ̈̈nden tablolaştırılmamıştır. Purutcuoğlu ve Bayraktar [27]'ın yürüttüğü çalışmada da lise öğrencilerinin ambalajlı gıda ürünlerinde son kullanma tarihi ve üretim tarihini okuma tutumu ile cinsiyet arasında anlamlı farklılık olduğu bulunmuştur $(\mathrm{P}<0.05)$.

Cinsiyete göre, tüketicilerin gıdayı hijyenik şartlarda hazırlama ve saklama konusundaki tutumları ile ilgili ifadelere verdikleri cevaplar incelendiğinde; "Çiğ ve pişmiş gıdayı yanyana saklamam." ifadesine; kadınların \%72.8'i (n=158) kesinlikle katılırken; \%20.7'si kısmen katılmıs, \%6.5'i kesinlikle katılmamıştır. Erkeklerin ise, \%53.2'si "kesinlikle katılıyorum", \%32.4'ü "kısmen katılıyorum", \%14.4'ü "kesinlikle katılmıyorum" cevabını vermiştir $(\mathrm{P}<0.05)$. "Ürünleri saklarken ya da pişirirken ambalajdaki talimatlara uyarım." ifadesine kadın tüketicilerin \%63.1'i, erkek tüketicilerin ise \%51.1'i "kesinlikle katılıyorum" yanıtını vermiştir (Tablo 3). Baysan [28]'ın çalışmasında cinsiyet ile arasında anlamlı farkın çıktığı tek tutum "ürünleri saklarken ya da pişirirken üzerindeki talimata uyma" $(\mathrm{t}=-3.500, \mathrm{P}<0.01)$ olmuştur. 
Cinsiyete göre, tüketicilerin gıda güvenliği ile ilgili konulardaki bilgi düzeyleri ve davranışları ile ilgili ifadelere verdikleri yanıtlara bakıldığında; "Ürünün lezzetinden çok besleyici olmas1 önemlidir." ifadesine kadınların \%49.8'i kesinlikle katıldığını, \%46.5'i kısmen katıldığını, \%3.7'si kesinlikle katılmadığını ifade etmiş̧ir. Sözkonusu ifadeye erkeklerin ise \%53.7'sinin kesinlikle katıldığ1, \%34.6'sının kısmen katıldığı, \%11.7'sinin kesinlikle katılmadı̆̆ bulunmuştur ( $\mathrm{P}<0.05)$ (Tablo 3).

Cinsiyete göre, tüketicilerin gıda güvenliği ve gıda hijyeni ile ilgili bilgi ve tutumlarını ölçmeye yarayan ifadelere verdikleri yanıtlar arasında anlamlı fark olup olmadığı analiz edildiğinde; sadece 9 ifade dışında diğer ifadelere verdikleri yanıtlar arasında anlamlı fark olmadığının bulunması katılımcıların gıda güvenliği ve hijyen konusunda doğru bilgi veya doğru alışkanlık sahibi olmaları ile cinsiyet arasındaki ilişkinin beklenildiği şekilde olmadığı belirlenmiştir.

Tüketicilerin 1. (1. ve 6. ifadeler), 2. (11. ve 12. ifadeler) 3. (14., 18. ve 25. ifadeler) ve 4. (29., 36. ve 38. ifadeler) faktörlere verdikleri yanıtların eğitim düzeyine göre değişimi $(\mathrm{P}<0.05)$ Tablo 4 'te verilmiştir. Eğitimi olmayan kişilerin sayısı $<30$ olduğu için ilköğretim mezunu, lise mezunu ve üniversite mezunu kişilerin yanıtları karşılaştırılmıştır.

Tüketicilerin eğitim düzeyine göre, gıda ürünü satın almadaki bilinç düzeyleri ile ilgili ifadeler incelendiğinde; "Satın aldığım gıda ürünlerinin etiket bilgilerini okurum." ifadesine üniversite mezunlarının \%68.5'i, ilköğretim mezunlarının ise \%47.5'i kesinlikle katıldığını belirtmiştir $(\mathrm{P}<0.05)$ (Tablo 4).

Tüketicilerin eğitim düzeyine göre, gıda ürünü satın almadaki etkilendikleri faktörler ile ilgili ifadelere bakıldığında; "İndirimli veya promosyonlu olan ürünler satın almamda etkilidir." ifadesine üniversite mezunlarının \%51.3'ü, lise mezunlarının \%46.4'ü kısmen katılmıştır ( $\mathrm{P}<0.05)$ (Tablo 4).

Eğitim düzeyinin gıda satın alma tercihlerini etkilediği bildirilmektedir. Eğitim düzeyi yüksek olan bir tüketici ile eğitim düzeyi düşük olan tüketici arasında gıda ürünü satın alma kararında önemli farklılıkların bulunduğu; eğitim düzeyi düşük olan tüketicilerin, eğitim düzeyi yüksek olan tüketiciler kadar marka, fiyat, promosyon ve reklam gibi satın alma kararında etkili olan faktörler hakkında aynı düzeyde bilgiye sahip olmadıkları belirtilmektedir [53, 54]. Cutura [55]'nın gerçekleştirdiği araştırmada, tüketicinin eğitim düzeyi ve yaşadığı çevrenin satın alma davranışlarında önemli bir yere sahip olduğu belirlenmiştir.

Onurlubaş ve Gürler [12]'in araştırmasında eğitim değişkeninin \%1 düzeyinde istatistiksel olarak önemli olduğu bulunmuştur. Eğitim seviyesindeki 1 birimlik artışın tüketicilerin gıda güvenliği ile ilgili bilinç sahibi olma olasılığını 1.582 arttırdığı tespit edilmiştir [12]. Küçükköse [56]'nin yürüttüğü araştırmada ortaöğretim ve yükseköğretim düzeyindeki tüketicilerin, gıda satın alırken çoğunlukla ambalajın gıdaya uygunluğuna ve sağlam olmasına dikkat ettikleri saptanmışken, bizim çalışmamızda "Ürünü satın alırken ambalajın sağlam olup olmadığına dikkat ederim." ifadesine verilen yanıtlar ile eğitim düzeyi arasındaki farkın anlamlı olmadığı $(\mathrm{P}>0.05)$ görüldüğünden tablolaştırılmamıştır.

Tüketicilerin eğitim düzeyine göre, gıdayı hijyenik şartlarda hazırlama ve saklama konusundaki tutumları ile ilgili ifadeler incelendiğinde; "Çiğ ve pişmiş gıdayı yan yana saklamam." ifadesine üniversite mezunlarının \%57.9'u lise mezunlarının 77.4'ü "kesinlikle katılıyorum" yanıtını vermiştir. "Hormonsuz gıda ürünleri için fazla para öderim." ifadesine lise mezunlarının \%41.7'si, ilköğretim mezunlarının \%22.5'i kesinlikle katıldı̆̆ını ifade etmiştir ( $\mathrm{P}<0.05)$ (Tablo 4).

"Markalı ürünler her zaman kaliteli ve güvenilirdir." ifadesine üniversite mezunlarının \%30.0’u "kesinlikle katılmıyorum", ilköğretim mezunlarını \%37.5'i ise "kesinlikle katılıyorum" yanıtını vermiştir $(\mathrm{P}<0.05)$ (Tablo 4). Onurlubaş ve Gürler [12]'in araştırmasında eğitim seviyesi arttıkça markalı ürün satın alma tutumunda fiyatın önemli olmadığı tespit edilmiştir.

"İndirimli veya promosyonlu olan ürünler satın almamda etkilidir." ifadesine üniversite mezunlarının \%34.4'ü, ilköğretim mezunlarının \%57.5'i "kesinlikle katılıyorum" yanıtını vermiştir $(\mathrm{P}<0.05)$ (Tablo 4). Onurlubaş ve Gürler [12]'in araştırmasında da "promosyon ve satış arttırıcı kampayaları" eğitim seviyesi düşük olan tüketicilerin eğitim seviyesi yüksek olan tüketicilerden daha önemli buldukları ortaya çıkmıştır. Unusan [57]'ın 458 tüketici ile gerçekleştirdiği, evde gıda güvenliği bilgisi ve uygulamaları konusundaki çalışmasında eğitim düzeyinin artmasıyla beraber gıda güvenliği hakkındaki bilgilerin arttığı, ancak eğitim düzeyi ile gıda güvenliği ile ilgili davranışların olumlu olması arasında anlamlı bir ilişki olmadığı $(\mathrm{P}>0.05)$ ortaya konmuştur. 
Tablo 4. Tüketicilerin 1. (1. ve 6. ifadeler), 2. (11. ve 12. ifadeler) 3. (14., 18. ve 25. ifadeler) ve 4. (29., 36. ve 38. ifadeler) faktörlere verdikleri yanıtların eğitim düzeyine göre değişimi $(\mathrm{P}<0.05)$

\begin{tabular}{|c|c|c|c|c|}
\hline Ífadeler & Eğitim Düzeyi & $\begin{array}{l}\text { Kesinlikle } \\
\text { katılıyorum } \\
\quad \text { s }(\%)\end{array}$ & $\begin{array}{l}\text { Kismen } \\
\text { katılıyorum } \\
\quad \text { s }(\%)\end{array}$ & $\begin{array}{c}\text { Kesinlikle } \\
\text { katılmıyorum } \\
\text { s }(\%)\end{array}$ \\
\hline \multicolumn{5}{|l|}{$\begin{array}{l}\text { Gıda ürünü satın almadaki bilinç düzeyleri ile ilgili } \\
\text { ifadeler }\end{array}$} \\
\hline \multirow{3}{*}{$\begin{array}{l}\text { Satın aldığım gıda ürünlerinin etiket bilgilerini } \\
\text { okurum. }\end{array}$} & İlköğretim mezunu & $19(47.5)$ & $15(37.5)$ & $6(15.0)$ \\
\hline & Lise mezunu & $51(60.7)$ & $28(33.3)$ & $5(6.0)$ \\
\hline & Üniversite mezunu & $187(68.5)$ & $83(30.4)$ & $3(1.1)$ \\
\hline \multirow{3}{*}{$\begin{array}{l}\text { Yiyecek maddelerinin satıldığı yerin koşullarına } \\
\text { (temizlik, hijyen, rutubet) dikkat ederim. }\end{array}$} & İlköğretim mezunu & $36(90.0)$ & $4(10.0)$ & $0(0.0)$ \\
\hline & Lise mezunu & $60(71.4)$ & $24(28.6)$ & $0(0.0)$ \\
\hline & Üniversite mezunu & $223(81.7)$ & $44(16.1)$ & $6(2.2)$ \\
\hline \multicolumn{5}{|l|}{$\begin{array}{l}\text { Gıda ürünü satın almadaki etkilendikleri faktörler } \\
\text { ile ilgili ifadeler }\end{array}$} \\
\hline \multirow{3}{*}{ Gıda ürününün fiyatı karar vermemde önemlidir. } & İlköğretim mezunu & $25(62.5)$ & $15(37.5)$ & $0(0.0)$ \\
\hline & Lise mezunu & $44(52.4)$ & $29(34.5)$ & $11(13.1)$ \\
\hline & Üniversite mezunu & $112(41.0)$ & $120(44.0)$ & $41(15.0)$ \\
\hline \multirow{3}{*}{$\begin{array}{l}\text { İndirimli veya promosyonlu olan ürünler satın } \\
\text { almamda etkilidir. }\end{array}$} & İlköğretim mezunu & $23(57.5)$ & $16(40.0)$ & $1(2.5)$ \\
\hline & Lise mezunu & $36(42.9)$ & $39(46.4)$ & $9(10.7)$ \\
\hline & Üniversite mezunu & $94(34.4)$ & $140(51.3)$ & $39(14.3)$ \\
\hline \multicolumn{5}{|l|}{$\begin{array}{l}\text { Gıdayı hijyenik şartlarda hazırlama ve saklama } \\
\text { konusundaki tutumları ile ilgili ifadeler }\end{array}$} \\
\hline \multirow{3}{*}{$\begin{array}{l}\text { Ürünleri saklarken ya da pişirirken ambalajdaki } \\
\text { talimatlara uyarım. }\end{array}$} & İlköğretim mezunu & $18(45.0)$ & $16(40.0)$ & $6(15.0)$ \\
\hline & Lise mezunu & $43(51.2)$ & $29(34.5)$ & $12(14.3)$ \\
\hline & Üniversite mezunu & $170(62.3)$ & $88(32.2)$ & $15(5.5)$ \\
\hline \multirow{3}{*}{ Çiğ ve pişmiş gıdayı yan yana saklamam. } & İlköğretim mezunu & $28(70.0)$ & $10(25.0)$ & $2(5.0)$ \\
\hline & Lise mezunu & $65(77.4)$ & $15(17.9)$ & $4(4.8)$ \\
\hline & Üniversite mezunu & $158(57.9)$ & $80(29.3)$ & $35(12.8)$ \\
\hline \multirow{3}{*}{$\begin{array}{l}\text { Buzdolabından çıkardığım yemeği yemeden önce en } \\
\text { az } 75^{\circ} C^{\circ} \text { ye kadar ısıtırım. }\end{array}$} & İlköğretim mezunu & $8(20.0)$ & $18(45.0)$ & $14(35.0)$ \\
\hline & Lise mezunu & $29(34.5)$ & $36(42.9)$ & $19(22.6)$ \\
\hline & Üniversite mezunu & $109(39.9)$ & $117(42.9)$ & $47(17.2)$ \\
\hline \multicolumn{5}{|l|}{$\begin{array}{l}\text { Gıda güvenliği ile ilgili konulardaki bilgi düzeyleri } \\
\text { ve davranışları ile ilgili ifadeler }\end{array}$} \\
\hline \multirow{3}{*}{$\begin{array}{l}\text { Yiyeceklerin protein ve vitamin içeriklerini bilirim, } \\
\text { bilmediklerimi ögrenmeye gayret ederim. }\end{array}$} & İlköğretim mezunu & $7(17.5)$ & $15(37.5)$ & $18(45.0)$ \\
\hline & Lise mezunu & $37(44.0)$ & $38(45.2)$ & $9(10.7)$ \\
\hline & Üniversite mezunu & $123(45.1)$ & $114(41.8)$ & $36(13.2)$ \\
\hline \multirow{3}{*}{ Hormonsuz gıda ürünleri için fazla para öderim. } & İlköğretim mezunu & $9(22.5)$ & $24(60.0)$ & $7(17.5)$ \\
\hline & Lise mezunu & $35(41.7)$ & $34(40.5)$ & $15(17.9)$ \\
\hline & Üniversite mezunu & $151(55.3)$ & $90(33.0)$ & $32(11.7)$ \\
\hline \multirow{3}{*}{ Markalı ürünler her zaman kaliteli ve güvenilirdir. } & İlköğretim mezunu & $15(37.5)$ & $14(35.0)$ & $11(27.5)$ \\
\hline & Lise mezunu & $23(27.4)$ & $46(54.8)$ & $15(17.9)$ \\
\hline & Üniversite mezunu & $54(19.8)$ & $137(50.2)$ & $82(30.0)$ \\
\hline
\end{tabular}

Çelik ve Ünver [58]'in Ankara'da değişik kurumlarda çalışmakta olan erkek ve kadın tüketiciler ve ev hanımları ile yürüttüğü araştırmasında tüketicilerin eğitim seviyesi arttıkça gıda kontrolüyle ilgili bilgilerinin de arttığı belirlenmiştir.

Tüketicilerin eğitim düzeyine göre gıda güvenliği ve gıda hijyeni ile ilgili bilgi ve tutumlarını ölçmeye yarayan ifadelere verdikleri yanıtlar arasında anlamlı fark olup olmadığı analiz edildiğinde; sadece 10 ifade dışında diğer ifadelere verdikleri yanıtlar arasında anlamlı fark olmadığının bulunması katılımcıların gıda güvenliği ve hijyen konusunda doğru bilgi veya doğru alışkanlık sahibi olmaları ile eğitim seviyesi arasındaki iliş̧inin beklenildiği şekilde olmadığı saptanmıştır.

Tüketicilerin mesleklerine göre ifadelere verdikleri yanıtlar arasında anlamlı fark olup olmadığ 1 değerlendirilirken; sayısı $<30$ olan meslekler dahil edilmemiş, büro memuru, ev hanımı, öğrenci ve hemşirelerin ifadeleri analiz edilmiştir. Tüketicilerin 1. (1., 3. ve 5. ifadeler), 3. (15., 17., 18., 19., 22. ve 24. ifadeler) ve 4. (29., 30., 35. ve 36. ifadeler) faktörlere verdikleri yanıtların bazı mesleklere (büro memuru, ev hanımı, öğrenci ve hemşire) göre değişimi $(\mathrm{P}<0.05)$ Tablo 5 'te verilmiştir.

Bazı tüketicilerin mesleklerine göre, gıda ürünü satın almadaki bilinç düzeyleri ile ilgili ifadeler incelendiğinde; "Ürünü satın alırken ambalajın sağlam olup olmadığına dikkat ederim." ifadesine büro memurlarının \%82.4'ünün, hemşirelerin ise \%78.1'inin "kesinlikle katılıyorum" yanıtını verdiği belirlenmiştir $(\mathrm{P}<0.05)$ (Tablo 5). 
Bazı tüketicilerin mesleklerine göre, gıdayı hijyenik şartlarda hazırlama ve saklama konusundaki tutumları ile ilgili ifadeler incelendiğinde; "Yemeği karıştırdığım kepçeyle yemeğin tadına bakmam." ifadesine ev hanımlarının \%9.1'i, öğrencilerin ise \%20.9'u kesinlikle katılmadığını dile getirmiştir. "Çiğ ve pişmiş etleri, sebzeleri hazırlarken farklı bıçak ve kesme tahtası kullanırım." ifadesine ev hanımlarının \%60.6'sının, hemşirelerin ise \%\%46.9'unun kesinlikle katıldığı görülmüştür $(\mathrm{P}<0.05)$ (Tablo 5).

Bazı tüketicilerin mesleklerine göre, gıda güvenliği ile ilgili konulardaki bilgi düzeyleri ve davranışları ile ilgili ifadelere bakıldığında; "Besin değeri iyi olan gıdalar daha pahalıdır." ifadesine büro memurlarının \%15.3'ü, öğrencilerin ise \%20.9'u kesinlikle katılmadığını ifade etmiştir $(\mathrm{P}<0.05)$ (Tablo 5).

Köse ve Yaman [32]'ın Kastamonu ili Merkez ilçesindeki 116 tüketici ile yaptıkları çalışmasında tüketicilerin son kullanma tarihine verdikleri önemin mesleklere göre önemsenme tutumunun \%66.7-\% 77.5 arasında olduğu tespit edilmiştir.

Tüketicilerin mesleklerine göre gıda güvenliği ve gıda hijyeni ile ilgili bilgi ve tutumlarını ölçmeye yarayan ifadelere verdikleri yanıtlar arasında anlamlı fark olup olmadığı analiz edildiğinde; sadece 12 ifade dışında diğer ifadelere verdikleri yanıtlar arasında anlamlı fark olmadığının bulunması katılımcıların gıda güvenliği ve hijyen konusunda doğru bilgi veya doğru alışkanlık sahibi olmaları ile meslek arasındaki ilişkinin beklenildiği şekilde olmadığı gözlemlenmiştir.

Tablo 5. Tüketicilerin 1. (1., 3. ve 5. ifadeler), 3. (15., 17., 18., 19., 22. ve 24. ifadeler) ve 4. (29., 30., 35. ve 36. ifadeler) faktörlere verdikleri yanıtların bazı mesleklere (büro memuru, ev hanımı, öğrenci ve hemşire) göre değişimi $(\mathrm{P}<0.05)$

\begin{tabular}{|c|c|c|c|c|}
\hline Iffadeler & Meslek & $\begin{array}{c}\text { Kesinlikle } \\
\text { katılıyorum } \\
\text { s }(\%)\end{array}$ & $\begin{array}{c}\text { Kısmen } \\
\text { katılıyorum } \\
\text { s }(\%)\end{array}$ & $\begin{array}{c}\text { Kesinlikle } \\
\text { katılmiyorum } \\
\text { s (\%) }\end{array}$ \\
\hline \multicolumn{5}{|l|}{$\begin{array}{l}\text { Gıda ürünü satın almadaki bilinç düzeyleri ile ilgili } \\
\text { ifadeler }\end{array}$} \\
\hline \multirow{4}{*}{$\begin{array}{l}\text { Satın aldığım gıda ürünlerinin etiket bilgilerini } \\
\text { okurum. }\end{array}$} & Büro memuru & $92(70.2)$ & $38(29.0)$ & $1(0.8)$ \\
\hline & Ev hanımı & $26(39.4)$ & $29(43.9)$ & $11(16.7)$ \\
\hline & Öğrenci & $27(62.8)$ & $16(37.2)$ & $0(0.0)$ \\
\hline & Hemşire & $23(71.9)$ & $9(28.1)$ & $0(0.0)$ \\
\hline \multirow{4}{*}{$\begin{array}{l}\text { Ürünü satın alırken ambalajın sağlam olup olmadığına } \\
\text { dikkat ederim. }\end{array}$} & Büro memuru & $108(82.4)$ & $21(16.0)$ & $2(1.5)$ \\
\hline & Ev hanımı & $52(78.8)$ & $12(18.2)$ & $2(3.0)$ \\
\hline & Öğrenci & $33(76.7)$ & $5(11.6)$ & $5(11.6)$ \\
\hline & Hemşire & $25(78.1)$ & 7 (21.9) & $0(0.0)$ \\
\hline \multirow{4}{*}{$\begin{array}{l}\text { Satın aldığım ürünün insan sağlığına olumsuz etkisi } \\
\text { olup olmadığına dikkat ederim. }\end{array}$} & Büro memuru & $94(71.8)$ & $37(28.2)$ & $0(0.0)$ \\
\hline & Ev hanımı & $34(51.5)$ & $25(37.9)$ & $7(10.6)$ \\
\hline & Öğrenci & $28(65.1)$ & $11(25.6)$ & $4(9.3)$ \\
\hline & Hemşire & $22(68.8)$ & $9(28.1)$ & $1(3.1)$ \\
\hline \multicolumn{5}{|l|}{$\begin{array}{l}\text { Gıdayı hijyenik şartlarda hazırlama ve saklama } \\
\text { konusundaki tutumları ile ilgili ifadeler }\end{array}$} \\
\hline \multirow{4}{*}{ Dondurulmuş gıdayı buzdolabında çözündürürüm. } & Büro memuru & $38(29.0)$ & $48(36.6)$ & $45(34.4)$ \\
\hline & Ev hanımı & $33(50.0)$ & $15(22.7)$ & $18(27.3)$ \\
\hline & Öğrenci & $11(25.6)$ & $21(48.8)$ & $11(25.6)$ \\
\hline & Hemşire & $8(25.0)$ & $16(50.0)$ & $8(25.0)$ \\
\hline \multirow{4}{*}{$\begin{array}{l}\text { Yemeği karıştırdığım kepçeyle yemeğin tadına } \\
\text { bakmam. }\end{array}$} & Büro memuru & $59(45.0)$ & $42(32.1)$ & $30(22.9)$ \\
\hline & Ev hanımı & $40(60.6)$ & $20(30.3)$ & $6(9.1)$ \\
\hline & Öğrenci & $14(32.6)$ & $20(46.5)$ & $9(20.9)$ \\
\hline & Hemşire & $14(43.8)$ & $15(46.9)$ & $3(9.4)$ \\
\hline \multirow{4}{*}{ Çiğ ve pişmiş gıdayı yan yana saklamam. } & Büro memuru & $76(58.0)$ & $35(26.7)$ & $20(15.3)$ \\
\hline & Ev hanımı & $52(78.8)$ & $12(18.2)$ & $2(3.0)$ \\
\hline & Öğrenci & $22(51.2)$ & $15(34.9)$ & $6(14.0)$ \\
\hline & Hemşire & $25(78.1)$ & $5(15.6)$ & $2(6.3)$ \\
\hline
\end{tabular}


Tablo 5 (devamı).

\begin{tabular}{|c|c|c|c|c|}
\hline İfadeler & Meslek & $\begin{array}{l}\text { Kesinlikle } \\
\text { katılıyorum } \\
\text { s (\%) }\end{array}$ & $\begin{array}{c}\text { Kısmen } \\
\text { katılıyorum } \\
\text { s }(\%)\end{array}$ & $\begin{array}{c}\text { Kesinlikle } \\
\text { katılmiyorum } \\
\text { s (\%) }\end{array}$ \\
\hline \multicolumn{5}{|l|}{$\begin{array}{l}\text { Gıdayı hijyenik şartlarda hazırlama ve saklama } \\
\text { konusundaki tutumları ile ilgili ifadeler }\end{array}$} \\
\hline \multirow{4}{*}{ Yiyecekleri plastik kaplarda uzun süre bekletmem. } & Büro memuru & $62(47.3)$ & $40(30.5)$ & $29(22.1)$ \\
\hline & Ev hanımı & $40(60.6)$ & $16(24.2)$ & $10(15.2)$ \\
\hline & Öğrenci & $20(46.5)$ & $17(39.5)$ & $6(14.0)$ \\
\hline & Hemşire & $15(46.9)$ & $17(53.1)$ & $0(0.0)$ \\
\hline \multirow{4}{*}{$\begin{array}{l}\text { Pişmiş yemekleri soğuduktan sonra buzdolabında } \\
\text { saklarım, dışarıda bırakmam. }\end{array}$} & Büro memuru & $79(60.3)$ & $38(29.0)$ & $14(10.7)$ \\
\hline & Ev hanımı & $38(57.6)$ & $25(37.9)$ & $3(4.5)$ \\
\hline & Öğrenci & $22(51.2)$ & $19(44.2)$ & $2(4.7)$ \\
\hline & Hemşire & $13(40.6)$ & $12(37.5)$ & $7(21.9)$ \\
\hline \multicolumn{5}{|l|}{$\begin{array}{l}\text { Gıda güvenliği ile ilgili konulardaki bilgi düzeyleri } \\
\text { ve davranışları ile ilgili ifadeler }\end{array}$} \\
\hline \multirow{4}{*}{$\begin{array}{l}\text { Yiyeceklerin protein ve vitamin içeriklerini bilirim, } \\
\text { bilmediklerimi öğrenmeye gayret ederim. }\end{array}$} & Büro memuru & $60(45.8)$ & $50(38.2)$ & $21(16.0)$ \\
\hline & Ev hanımı & $14(21.2)$ & $29(43.9)$ & $23(34.8)$ \\
\hline & Öğrenci & $17(39.5)$ & $21(48.8)$ & $5(11.6)$ \\
\hline & Hemşire & $13(40.6)$ & $18(56.3)$ & $1(3.1)$ \\
\hline \multirow{4}{*}{$\begin{array}{l}\text { Yiyecekleri yıkamada veya yemek hazırlamada } \\
\text { kullandığım suyun temizliğine dikkat ederim. }\end{array}$} & Büro memuru & $108(82.4)$ & $19(14.5)$ & $4(3.1)$ \\
\hline & Ev hanımı & $62(93.9)$ & $4(6.1)$ & $0(0.0)$ \\
\hline & Öğrenci & $34(79.1)$ & $3(7.0)$ & $6(14.0)$ \\
\hline & Hemşire & $27(84.4)$ & $4(12.5)$ & $1(3.1)$ \\
\hline \multirow{4}{*}{ Besin değeri iyi olan gıdalar daha pahalıdır. } & Büro memuru & $63(48.1)$ & $48(36.6)$ & $20(15.3)$ \\
\hline & Ev hanımı & $26(39.4)$ & $25(37.9)$ & $15(22.7)$ \\
\hline & Öğrenci & $20(46.5)$ & $14(32.6)$ & $9(20.9)$ \\
\hline & Hemşire & $6(18.8)$ & $21(65.6)$ & $5(15.6)$ \\
\hline \multirow{4}{*}{ Hormonsuz gıda ürünleri için fazla para öderim. } & Büro memuru & $70(53.4)$ & $48(36.6)$ & $13(9.9)$ \\
\hline & Ev hanımı & $17(25.8)$ & $38(57.6)$ & $11(16.7)$ \\
\hline & Öğrenci & $18(41.9)$ & $16(37.2)$ & $9(20.9)$ \\
\hline & Hemşire & $17(53.1)$ & $10(31.3)$ & $5(15.6)$ \\
\hline
\end{tabular}

\section{Sonuç ve Öneriler}

Tüketicilerin gıda güvenliği ve gıda hijyeni ile ilgili tutumlarını belirleyen ifadelere verilen yanıtlara göre; eğitim düzeyi yüksek kişilerin doğru bilgi veya doğru alışkanlık sahibi olmaları arasında önceki çalışmalarda (Onurlubaş ve Gürler [12], Küçükköse [56], Çelik ve Ünver [58]) belirtildiği şekilde, beklenildiği düzeyde olumlu bir ilişkinin olmadığı anlaşılmıştır. Sağlık [26] ve Purutcuoğlu ve Bayraktar [27]'ın çalışmalarından farklı olarak cinsiyet ile gıda güvenliği ve gıda hijyeni ile ilgili ifadelere verilen yanıtlar arasında, dokuz ifade dışında anlamlı fark olmadığı $(\mathrm{P}>0.05)$ belirlenmiştir. Cinsiyet ve eğitim düzeyi fark etmeksizin, bazı tüketicilerin hem doğru bilgiye sahip olma, hem de gida güvenliği ve gida hijyeni ile ilgili tutumlarında yanlış ve eksikliklerin olduğu görülmüştür.

Gıda güvenliği ve gıda hijyenini yeterince sağlayabilmek ve bunları sürdürmek için Dünya Sağlık Örgütünün 10 altın kuralını (1. Gıda işleme için güvenli gıda seçilmelidir, 2. Gıdalar tam olarak pişirilmelidir, 3. Pişmiş gıdalar vakit geçirmeksizin yenmelidir, 4. Pişirilmiş gıdalar dikkatlice saklanmalıdır, 5. Tekrar isıtılan gıdanın her tarafının sıcaklığının en az $70{ }^{\circ} \mathrm{C}$ 'ye ulaşması gerekmektedir, 6. Pişirilmiş gıdalar ile çiğ gıdaların birbirleri ile temasından kaçınılmalıdır, 7. Kişisel temizlik kurallarına uyulmalıdır, 8. Tüm mutfak yüzeyleri temiz tutulmalıdır, 9. Gıdalar böceklerden, kemirgenlerden ve diğer hayvanlardan korunmalıdır, 10. Güvenli ve temiz su kullanılmalıdır) asla unutmamak gerekmektedir. Gida güvenliği ve gida hijyeni konusunda, toplumun her kesimi bilgilendirilmeli, öğrenilen bilginin doğru şekilde uygulanması ve alışkanlık haline dönüştürülmesini sağlayacak farklı eğitim programları düzenlenmelidir.

\section{Yazarların Katkısı}

Yazar araştırmanın planlanması, anket sorularının düzenlenmesi, verilerin toplanması, verilerin değerlendirilmesi, bulguların yorumlanması ve makalenin yazımı olmak üzere bütün aşamaları kendisi yürütmüştür. 


\section{Çıkar Çatışması Beyanı}

Yazarlar arasında herhangi bir çıkar çatışması bulunmamaktadır.

\section{Araştırma ve Yayın Etiği Beyanı}

Yapılan çalışmada araştırma ve yayın etiğine uyulmuştur.

\section{Kaynaklar}

[1] Bosi A.T. 2003. Gıda Güvenliği ve Güvencesi. Türk Belediyecilik Sempozyumu (SABEM). http://www.sabem.saglik.gov.tr/kaynaklar/2989.pdf. (Erişim Tarihi: 15.05.2019).

[2] Tayar M., Anar Ş., Soyutemiz E., Bostan K., Aksu H., Çıbık R. 2011. Hijyen ve Sanitasyon. Anadolu Üniversitesi, Yayın No: 2349, 218 s, Eskişehir.

[3] Özçiçek Dölekoğlu C. 2003. Tüketicilerin İşlenmiş Gıda Ürünlerinde Kalite Tercihleri, Sağlık Riskine Karşı Tutumları ve Besin Bileşimi Konusunda Bilgi Düzeyleri (Adana Örneği). TEAE, Yayın No: 105, Ankara.

[4] FAO/WHO 2002. Pan European Conference on Food Safety and Quality. http:/www.fao.org. (Erişim Tarihi: 15.05.2019).

[5] Kayaardı S. 2012. Gida Hijyeni ve Sanitasyon. Sidas, 252s. İzmir.

[6] Göktan D., Tunçel G. 2016. Temel Gıda Hijyeni. Sidas, 210s. İzmir.

[7] Kutluay Merdol T., Beyhan Y., Ciğerim N., Sağlam F., Tayfur M., Baş M., Dağ A. 2003. Toplu Beslenme Yapılan Kurumlarda Çalışan Personel İçin Sanitasyon/Hijyen Rehberi. Hatipoğlu Yayınlar1, 142s. Ankara.

[8] Rohs F.R., Langone C.A., Coleman, R.K. 2001. Response shift bias: a problem in evaluating nutrition training using self report measures. Society for Nutrition Education, 33 (3): 165-170.

[9] Türk İncel E. 2005. Yetişkin tüketicilerin besin güvenliği konusundaki bilgi ve davranışları. Yüksek Lisans Tezi, Hacettepe Üniversitesi, Sağlık Bilimleri Enstitüsü, Beslenme ve Diyetetik Anabilim Dalı, Ankara.

[10] Badrie N., Gobin A., Dookeran S., Duncan R. 2006. Consumer awareness and perception to food safety hazards in Trinidad West Indies. Food Control, 17 (5): 370-377.

[11] Jevsnik M. Hlebec V., Raspor P. 2008. Consumers' awareness of food safety from shopping to eating. Food Control, 19 (8): 737-745.

[12] Onurlubaş E., Gürler A.Z. 2016. Gıda güvenliği konusunda tüketicilerin bilinç düzeyini etkileyen faktörler. Gaziosmanpaşa Üniversitesi Ziraat Fakültesi Dergisi, 33 (1): 132-141.

[13] Tayar M., Kılıç V. 2014. Gıda Endüstrisinde Hijyen ve Sanitasyon. Dora Yayıncılık, 556s. Bursa.

[14] Topuzoğlu A., Hıdıroğlu S., Ay P., Önsüz F., İkiışık H. 2007. Tüketicilerin gıda ürünleri ile ilgili bilgi düzeyleri ve sağlık risklerine karşı tutumları. TSK Koruyucu Hekimlik Bülteni, 6 (4): 253 258.

[15] Üçüncü M. 2000. Gıdaların Ambalajlanması. Ege Üniversitesi Basımevi, 689s, İzmir.

[16] Alpuğuz G., Erkoç F., Mutluer B., Selvi M. 2009. Gençlerin (14-24 Yaş) gıda hijyeni ve ambalajlı gıdaların tüketimi konusundaki bilgi ve davranışlarının incelenmesi. Türk Hijyen ve Deneysel Biyoloji Dergisi, 66 (3): 107-115.

[17] İncedal Sonkaya Z., Balcı E., Ayar A. 2018. Üniversite öğrencilerinin gıda okuryazarlı̆̆ı ve gıda güvenliği konusunda bilgi, tutum ve davranışları "Amasya Üniversitesi Sabuncuoğlu Şerefeddin Sağlık Hizmetleri Meslek Yüksekokulu örneği”. Türk Hijyen ve Deneysel Biyoloji Dergisi, 75 (1): 53-64.

[18] Çalık N. 1999. Ürün, tüketici ve satış noktası özelliklerinin satın alma yeri ve satın alma şekli üzerindeki etkilerinin araştırılması gıda maddeleri ile ilgili bir uygulama. İktisadi ve İdari Bilimler Fakültesi, 4. Ulusal Pazarlama Kongresi, pp16-24,18-20 Kasım, Ankara.

[19] Kavas G., Kınık Ö. 2000. Gıdaların etiketlenmesi ve etiket standartlarına uygunluğunun incelenmesi. G1da Dergisi, 10: 77-85.

[20] Emeksiz F., Albayrak M., Güneş E., Özçelik A., Özer O.O., Taşdan K. 2005. Türkiye'de Tarımsal Ürünlerin Pazarlama Kanalları ve Araçların Değerlendirilmesi. Türkiye Ziraat Mühendisliği VI. Teknik Kongresi, 3-7 Ocak, Ankara, 2: 1155-1171. 
[21] Özgül E., Aksulu İ. 2006. Ambalajlı gıda ürünlerinde tüketicilerin etiket duyarlılığındaki değişimler. Ege Akademik Bakış Dergisi, 6 (1): 1-9.

[22] Kim S.Y., Nayga R., Capps O. 2001. Food label use, self-selectivity, and diet quality. Journal of Consumer Affairs, 35 (2): 346-363.

[23] APBN 2003. Increased popularity of food labels among consumers. Asia Pacific Biotech, Agriculture, 7 (23): 1502-1503. https://www.asiabiotech.com/07/0723/1501_1506.pdf (Erişim Tarihi: 25.06.2019).

[24] Yaman M., Özgen L. 2007. Üniversite öğrencilerinin yurtlarındaki besin hijyeni yaklaşımları ve besin hazırlama uygulamaları. Gazi Üniversitesi Endüstriyel Sanatlar Eğitim Fakültesi Dergisi, 20: 28-38.

[25] Yurdagül M. 1991. Tüketicilerin gida katkı maddeleri ile ilgili bilgi ve uygulamaları. Beslenme ve Diyet Dergisi, 20 (2): 199-208.

[26] Çınar R., Sağlık E. 2006. Perakende gıda ürünlerinde etiketin önemi, tüketiciler üzerindeki etkileri ve Erzurum ölçeğinde bir alan araştırması. Pazarlama Dünyası Dergisi, 1-10.

[27] Purutcuoğlu E., Bayraktar M. 2004. Investigating the need for consumer education among Turkish secondary school students. International Journal of Consumer Studies, 28 (5): 443-453.

[28] Baysan F. 2009. Hemşirelerin Gıda Ürünleri ile İlgili Sağlık Risklerine Karsı Tutumları. Yüksek Lisans Tezi, Selçuk Üniversitesi, Sağlık Bilimleri Enstitüsü, Halk Sağlığı Anabilim Dalı, Konya.

[29] Salicik D., Yıldırım Kumral A. 2017. Bursa ili kentsel alanında tüketicilerin güvenilir gıda tüketimine yönelik tutumlarının belirlenmesi. Uludağ Üniversitesi Ziraat Fakültesi Dergisi, 31 (2): 69-82.

[30] Kaptan M. 2007. Tüketicilerin Gıda Güvenliği Hakkındaki Bilgi Düzeylerinin Tespiti. Yüksek Lisans Tezi, Çanakkale Onsekiz Mart Üniversitesi, Fen Bilimleri Enstitüsü, Gıda Mühendisliği Ana Bilim Dalı, Çanakkale.

[31] Kılıç D. 2008. Tüketicilerin Gıda Güvenliği ile İlgili Bilgi-Tutum ve Davranışları. Yüksek Lisans Tezi, Gazi Üniversitesi, Eğitim Bilimleri Enstitüsü, Eğitim Bilimleri Bölümü, Ankara.

[32] Köse N., Yaman K. 2010. Tüketicilerin gıda maddelerinin son kullanma tarihine verdikleri önem üzerine bir araştırma: Kastamonu ili Merkez ilçe örneği. Kastamonu Eğitim Dergisi, 18 (1): 233240.

[33] Kızılaslan H., Yalçın A. 2012. Tüketicilerin Gıda Güvenliği ile İlgili Tutum ve Davranışları Samsun İli Örneği. Tarımsal Ekonomi ve Politika Geliştirme Enstitüsü, Yayın No: TEPGE: 213.

[34] Schucker R.E., Levy A.S., Tenney J.E., Mathews O. 1992. Nutrition shelf-labeling and consumer purchase behavior. Journal of Nutrition Education, 24 (2): 75-81.

[35] Mitchel P.M., Karslund M.K., Finan A., Johnson J. 1994. Food label reading habits of WIC clients. Journal of Nutrition Education, 26 (3): 146-148.

[36] Şanlıer N., Şeren S. 2005. Tüketicilerin besin satın alma bilinçlerinin değerlendirilmesi. Üçüncü Sektör Kooperatifçilik, 149: 12-29.

[37] Akdevelioğlu Y., Gümüş H., Şimşek I. 2013. University students' knowledge and practices of food safety, The Anthropologist, 16 (3): 677-684.

[38] Aras Okumuş B., Bulduk S. 2003. Tüketicilerin süpermarketlerdeki alışveriş alışkanlıkları ve ürün seçimini etkileyen etmenler. Dokuz Eylül Üniversitesi, Sosyal Bilimler Enstitüsü Dergisi, 5 (4): 70-83.

[39] Yılmaz E., Oraman Y., İnan İ.H. 2009. Gıda ürünlerine ilişkin tüketici davranış1 dinamiklerinin belirlenmesi: Trakya örneği. Tekirdağ Ziraat Fakültesi Dergisi, 6 (1): 1-10.

[40] Albayrak M. 2000. Ankara İlinde Gida Maddeleri Paketleme ve Etiketleme Bilgileri Hakkında Tüketicilerin Bilinç Düzeyinin Ölçülmesi, Gıda Maddeleri Alım Yerleri ve Ambalaj Tercihleri Üzerine Bir Çalışma. Türkiye Ziraat Odaları Birliği, Burcu Ofset Matbaacılık, 90s, Ankara.

[41] Uzunöz M., Büyükbay E., Bal S. 2008. Kırsal kadınların gıda güvenliği ile ilgili bilinç düzeyleri. Uludağ Üniversitesi Ziraat Fakültesi Dergisi, 22 (2): 35-46.

[42] Gözener B., Büyükbay E.O., Sayılı M. 2009. Gıda güvenliği konusunda öğrencilerin bilgi düzeylerinin incelenmesi. Gaziosmanpaşa Üniversitesi Ziraat Fakültesi Dergisi, 2: 45-53.

[43] Gülse Bal H.S., Göktolga Z.G., Karkacıer O. 2006. Gıda güvenliği konusunda tüketici bilincinin incelenmesi (Tokat ili örneği). Tarım Ekonomisi Dergisi, 12 (1): 9-18. 
[44] Modjuszka E., Caswell J. 2001. Consumer choice of food products and nutrition information. 71st Seminar of the European Association of Agricultural Economists, The Food Consumer in the Early 21st Century, 19-21 April, Zaragoza, Spain.

[45] Kızılaslan N., Kızılaslan H. 2008. Tüketicilerin satın aldıkları gıda maddeleri ile ilgili bilgi düzeyleri ve tutumları (Tokat ili örneği). Uludağ Üniversitesi Ziraat Fakültesi Dergisi, 22 (2): 67 74.

[46] Çınar R., Özer S. 1999. Gıda ürünlerinde etiketleme üniversite öğrencilerinin tutumları üzerine bir araştırma. Pazarlama Dünyası, 13 (74): 12-17.

[47] Demirağ K., Ova G., Gölge E., Düşel D., Akın V. 2003. Gıda reklamlarının tüketici üzerine etkileriyle ilgili bir araştırma. Dünya Gıda, 9 (12): 71-75.

[48] Kolodinsky J., Green J., Michahelles M., Harvey-Berino J.R. 2008. The use of nutritional labels by college students in a food-court setting. Journal of American College of Health, 57 (3): 297302.

[49] Onurlubaş E., Doğan H.G., Gürler A.Z. 2015. Türkiye'de ev dişı gıda tüketimin durumu ve tüketici eğilimleri. Uluslararası Sosyal Araştırmalar Dergisi, 8 (38): 917-924.

[50] Jay L.S., Comar D., Govenlock L.D. 1999. National Australian food safety telephone survey. Journal of Food Protection, 62 (8): 921-928.

[51] Bruhn Ç.M., Schutz H.G. 1999. Consumer food safety knowledge and practices. Journal of Food Safety, 19 (1): 73-87.

[52] Biloukha O.O., Utermohlen V. 2001. Healthy eating in Ukraine: attitudes, barriers and information sources. Public Health Nutrition, 4 (2): 207-215.

[53] Wilkie W. 1986. Consumer Behaviour. University of Florida, New York, USA.

[54] Asseal H. 1992. Consumer Behavior and Marketing Action. New York University, PSW-Kent Publishing Company, Boston, USA.

[55] Cutura M. 2006. The impacts of ethnocentrism on consumer evaluation processes and willingness to buy domestic vs. imported good in the case of Bosnia and Herzegovina. South East European Journal of Economics and Business, 1 (2): 54-63.

[56] Küçükköse Ş. 2002. Farklı Öğrenim Düzeyindeki Tüketicilerin Süpermarketlerden Gıda Alışverişlerinde Etkilendikleri Faktörler. Yüksek Lisans Tezi, Gazi Üniversitesi, Eğitim Bilimleri Enstitüsü, Aile Ekonomisi ve Beslenme Anabilim Dalı, Ankara.

[57] Unusan N. 2007. Consumer food safety knowledge and practices in the home in Turkey. Food Control, 18 (1): 45-51.

[58] Çelik Ş., Ünver B. 1991. Tüketicilerin cinsiyet, eğitim, çalışma durumlarına göre gıda kontrolü hakkındaki bilgileri. Gıda Dergisi, 16 (5): 333-340. 